\title{
INTERNATIONAL FISHERIES
}

Y 4. C 73/7: S. HRG. 103-721

International Fisheries, S.Hrg. 103...

\section{HEARING}

BEFORE THE

\section{COMMITTEE ON COMMERCE, SCIENCE, AND TRANSPORTATION UNITED STATES SENATE ONE HUNDRED THIRD CONGRESS \\ SECOND SESSION \\ JULY 21, 1994}

Printed for the use of the Committee on Commerce, Science, and Transportation
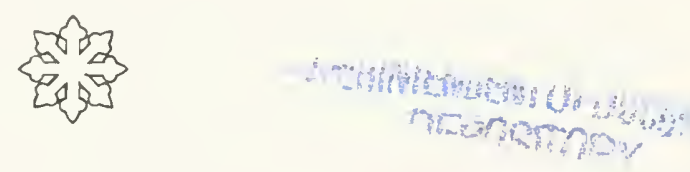

$\operatorname{MON} 2$

U.S. GOVERNMENT PRINTING OFFICE 



\section{INTERNATIONAL FISHERIES}

Y 4. C 73/7: S. HRG. 103-721

International Fisheries, S.Hrg. 103...

\section{HEARING}

BEFORE THE

\section{COMMITTEE ON COMMERCE, SCIENCE, AND TRANSPORTATION \\ UNITED STATES SENATE \\ ONE HUNDRED THIRD CONGRESS}

SECOND SESSION

JULY 21, 1994

Printed for the use of the Committee on Commerce, Science, and Transportation

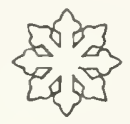

U.S. GOVERNMENT PRINTING OFFICE 


\section{COMMITTEE ON COMMERCE, SCIENCE, ANI TRANSPORTATION}

ERNEST F. HOLLINGS, South Carolina, Chairman

DANIEL K. INOUYE, Hawaii WENDELL H. FORD, Kentucky J. JAMES EXON, Nebraska JOHN D. ROCKEFELLER IV, West Virginia JOHN F. KERRY, Massachusetts JOHN B. BREAUX, Louisiana RICHARD H. BRYAN, Nevada CHARLES S. ROBB, Virginia BYRON L. DORGAN, North Dakota HARLAN MATHEWS, Tennessee
JOHN C. DANFORTH, Missouri BOB PACKWOOD, Oregon LARRY PRESSLER, South Dakota TED STEVENS, Alaska JOHN MCCAIN, Arizona CONRAD BURNS, Montana SLADE GORTON, Washington TRENT IOTT, Mississippi KAY BAILEY HUTCHISON, Texas

Kevin G. CurTIN, Chief Counsel and Staff Director Jonathan ChamBers, Republican Staff Director

(II) 


\section{O N T E N T S}

Opening statement of Senator Burns

Page

Prepared statement

Opening statement of Senator Hollings

Opening statement of Senator Kerry .....

Opening statement of Senator Stevens

\section{LIST OF WITNESSES}

Benton, David, Director, Office of External and International Fisheries, Alaska Department of Fish and Game

Prepared statement Prepared statement

Colson, Ambassador David A., Deputy Assistant Secretary of State for Oceans, Department of State

Prepared statement

Kaelin, Jeffrey H., Executive Director, Maine Sardine Council ....

Prepared statement

Martin, William E., Deputy Assistant Secretary of Commerce for International Affairs, Department of Commerce Prepared statement

Speer, Lisa, Senior Policy Analyst, Natural Resources Defense Council

\section{APPENDIX}

Greenpeace, National Resources Defense Council, World Wildlife Fund, Inc., and National Audubon Society, letter from, to David Colson, dated July 14,1994

National Resources Defense Council, National Audubon Society, and Center for Marine Conservation, prepared statement of 



\title{
INTERNATIONAL FISHERIES
}

\author{
THURSDAY, ЛULY 21, 1994
}

\author{
U.S. Senate, \\ Committee on Commerce, Science, and Transportation, \\ Washington, $D C$.
}

The committee met, pursuant to notice, at 10 a.m. in room SR253, Russell Senate Office Building, Hon. John F. Kerry, presiding.

Staff members assigned to this hearing: Penelope D. Dalton, senior professional staff member, and Lila H. Helms, professional staff member; and John A. Moran, minority staff counsel.

\section{OPENING STATEMENT OF SENATOR KERRY}

Senator KERRY. Good morning. The hearing will come to order. First, let me welcome some fellow legislators from the Taiwan Parliament who are here visiting us today. We are delighted to have you here sharing in this hearing. And we welcome all of our guests to these proceedings.

We meet this morning to address a topic of enormous concern to the committee and concern to all of us who have had anything to do with fisheries over the years. I am happy to welcome David Colson, the State Department's fishery ambassador, and Will Martin, who heads the International Affairs Office at the National Oceanic and Atmospheric Administration, NOAA.

They are going to provide testimony on behalf of the administration concerning the effect of ongoing multilateral discussions and agreements on Federal fishery programs and our responsibilities with respect to those programs.

We have also asked them today to identify other international issues that are likely to become a concern for our fishermen and also for our country's environment.

Following the administration testimony, we will welcome a distinguished panel of expert witnesses who will provide their views on several issues. Among them, David Benton, the director of external and international fisheries affairs of the Alaska Department of Fish and Game; David Burney, the executive director of the U.S. Tuna Foundation; Jeff Kaelin, the executive director of the Maine Sardine Council; and Ms. Lisa Speer, senior policy analyst with the Natural Resources Defense Council.

Thank you, all of you, for coming here today. Mr. Chairman, your comments, please.

\section{OPENING STATEMENT OF SENATOR HOLLINGS}

The CHAIRMAN. Earlier this year I requested publication in the Congressional Record of a Washington Post editorial by Jessica 
Mathews, entitled “Today's Catch-and Tomorrow's: An orgy of over-fishing is depleting the oceans and endangering future food supplies." This editorial discussed the crisis in global fisheries management, and emphasized the need to strengthen international fisheries management. Today's hearing focuses on these concerns, particularly the serious overfishing of world fish stocks.

According to the United Nations Food and Agriculture Organization, FAO, recent declines in fisheries harvest levels indicate a ceiling to what was once thought to be a limitless resource. A recent FAO report estimated that about 60 percent of all marine fish for which the population size is known are fully or overharvested or depleted.

The FAO attributes the depletion of once-abundant and valuable marine resources to improvements in fishing technology by large subsidized fishing fleets of industrialized nations. The size and efficiency of these modern fleets can exceed the productivity of their traditional coastal harvesting areas. Fishery managers of coastal nations have generally reacted to such excess harvesting capacity in their coastal fisheries by imposing stricter management regimes. As a result, some vessels have been displaced and have sought alternative fishing opportunities in distant waters. FAO warns that unless industrial fishing fleets are controlled through national and international regulation, there may be disastrous social and economic consequences for the entire industry.

The United States has taken the lead in promoting international fisheries conservation through its initiation of the multilateral Agreement to Promote Compliance With International Conservation and Management Measures by Fishing Vessels on the High Seas. The administration has transmitted implementing legislation to Congress, the High Seas Fisheries Licensing Act, which would establish a system of licensing, reporting, and regulation for American vessels fishing on the high seas. Three nations have already implemented the agreement, and U.S. action should prompt other nations to follow in the near future.

I applaud the administration for taking the lead to address global fisheries concerns, and I look forward to reviewing today's testimony from the administration, industry, and environmental organizations on continuing efforts to address these concerns.

Thank you, Mr. Chairman.

Senator KERRY. Thank you, Mr. Chairman. In the last few years, Senator Stevens and I and some others in the committee, but particularly Senator Stevens and I, have been involved in the effort to ban driftnets. And we have, on a number of occasions, signalled the committee's deep concern with the trends in international fishing practices.

We will shortly be marking up the Magnuson Fishery Conservation and Management Act in this committee, after doing a considerable amount of work and holding a series of hearings to examine the issues regarding the management of fisheries and international fishing concerns. I wish we were coming to this hearing capable of saying we are turning the corner, and, indeed, that things were getting significantly better, but they are not.

And I think if ever there was urgency, the urgency is greater today, notwithstanding some advances that we have made in the 
international arena with respect to driftnets, tuna, and other concerns. The fact is, though, that the once thought to be inexhaustible supplies of fish are rapidly disappearing. And every trend line indicates that.

It is evident from the United Nations studies by the Food and Agricultural Organization-FAO - that 13 out of 17 international fisheries are in jeopardy today. The seafood harvests of the oceans have multiplied nearly fivefold since the end of World War II, growing from an annual catch globally of about 18 million metric tons to a peak of about 86.5 million metric tons in 1989, though the figures on that differ-some people say as much as 100 million.

Since 1989, we do not disagree that there has been a decline, though there is some disagreement over the amount of declinewhether it is 2 or 4 million metric tons or so forth.

Fishery statisticians also tell us that they have seen a worldwide shift to less valuable species, and that most gains in world harvest levels over the last 10 years have come from increased landings in lower value species, such as Alaskan pollock or Chilean jack mackerel. So, taking that into account, the decline is even more dramatic.

Even more telling is the fact that the world's catch has declined despite a significant increase in effort. The size and efficiency of modern fleets, including vessels equipped with sophisticated satellite navigation and sonar detection, has simply outstripped the productivity of traditional fishing grounds worldwide.

Now, in the United States, we are struggling to address the overfishing of our coastal fisheries, including the collapse of cod and haddock stocks in New England. And we are obviously deeply concerned and sensitive to these issues, because this year our fishing is greatly reduced. We obtained an emergency allocation of resources to help deal with the dislocation of fishermen. And we are still facing a crisis in the New England fisheries.

There is a simple reason for what is happening internationally. There are too many boats of too sophisticated a character chasing too few fish. The problem is not unique to New England, it is worldwide. And quite simply, unless there is a worldwide urgent response to this, we have the potential to do to international fisheries what we have seen developing and developed countries do to resources and even to civilizations over the course of history.

I am told that Iceland and the European Union could cut their fleets by up to 40 percent and Norway by more than 50 percent and all three nations would still be able to maintain fishery harvests at today's levels. If that is not a dramatic statement about the overcapitalization of the industry, I do not know what is.

Now, as nations increase their efforts, we have seen a perversely uneconomical system emerge, where we are operating the world's fleets at a loss. The United Nations FAO reports that in 1989, it cost $\$ 92$ billion to land 72 billion dollars' worth of fish. So, as a result, we see the 13 of the 17 fisheries that I talked about in deep trouble.

We all know that fish rank as one of the most important food sources throughout the world, providing up to 40 percent of the protein for developing countries. But many of the most valuable species in the world markets are now becoming harder to find, and 
they are more costly as fishery stocks are depleted by pollution, by habitat destruction and by the relentless pursuit of the fleets that I have discussed previously.

The decline in populations of fish conversely increases the competition among nations, and increases the fishing effort. And so we, in a sense, strip away all aspects of the ecosystem, rather than allow them time to replenish.

Most of the ways in which this competition has been responded to have not positive. Some positive efforts, as I have mentioned, have taken place, but far too slowly. We in the United States extended our management of the coast out to 200 miles and others have done so. Canada has now attempted to extend the jurisdiction in the Atlantic beyond 200 miles to protect coastal fisheries. We have become embroiled in disputes over stocks that straddle coastal borders, such as our ongoing tug of war with Canada over the $\mathrm{Pa}$ cific salmon.

And we are also receiving reports of foreign fleets traveling throughout the world on the high seas, fishing both legally and illegally, as they try to locate the dwindling stocks of very valuable species, such as bluefin tuna and swordfish.

So, today we are going to focus on the challenge of building sustainable fisheries. It is an enormous challenge. And I want to see this administration step up to it and take the lead, because there is a desperate need for worldwide leadership to promote global fishery conservation.

We have made some progress on the driftnets. We have completed new international agreements to manage Pacific tuna and Bering Sea pollock. And although the Atlantic bluefin stock is of concern, as I have suggested, I think there is hope that our investment in strengthening the International Commission for the Conservation of Atlantic Tunas may pay off in restoring those stocks. That does not diminish the crisis that I have talked about.

I certainly applaud the FAO efforts to develop an international code of conduct, and I am glad the United States is seeking a binding agreement with respect to the U.N. Conference on High Seas Fisheries. I think it is critical we get a binding agreement with dispute resolution capacity.

I also think it is important, in view of these trends, to examine today the U.S. participation in the Northwest Atlantic Fisheries Organization-NAFO-in order to determine where we are headed.

Now, I would like to call to the attention of my colleagues and others a glaring example of what I am talking about that occurs right in my backyard, New England. Yesterday, a front-page story in the Boston Globe talks about lobstermen hauling up empty traps. It is a long story detailing the lobster decline in New England.

It is a decline that the article accurately points out has been going on for the last four consecutive years. We have known this. We have not only known it, but the Federal Government proposed to do something about it by extending the minimum lobster catch size by fractions of an inch. And that met with resistance from the fishermen. 
We have known this decline is taking place. The New England Fishery Management Council has been charged to do something about it, but action has not been taken.

We all understand the conflicts that exist within councils. We understand the procrastination and the self-interest that has dominated some decisions. We respect individual autonomy and democracy and the capacity of local communities to make their decisions. But they cannot refuse to make these decisions. And we now find that biologists and most fishermen say that local waters are being overfished. In the last 5 years, more lobstermen sinking more traps have begun scouring virtually every cove from Rhode Island to Maine, according to industry analysts. The feared result-a depleted stock of lobsters.

And it is very clear that we are simply not providing these lobsters the opportunity to recoup. Laddie Dexter, the President of the Massachusetts Lobstermen Association, estimates the number of traps in local waters has risen 30 percent in the last 5 years. This is disgraceful.

And the State of Massachusetts, which controls up to the 3-mile mark, which is where most of the lobster pots are, refused to cede to Federal suggestions that there be a larger minimum catch size, and so forth.

So, it is very simple, folks. This is the story, whether it is lobsters in New England, bluefin tuna, or squid, it does not matter. If we continue to permit the rape of the world's oceans, we are going to destroy the ecosystem, which is extraordinarily fragile. And we will not do it by fishing alone: we will do it by habitat destruction, by overdevelopment, by waste, and by the ruination of this extraordinary resource.

So, I think there is enormous urgency in what we are undertaking. And I am going to call on the Secretary of Commerce to review what has happened in New England, to make a determination whether or not there is a more urgent regimen that has to be placed into effect, call on the fishermen themselves, as the fishermen in Maine, I think, have done a better job of doing, of trying to set up a regimen of policing themselves.

If fishermen cannot police themselves, other people will do it for them, and it will not be pleasant. That is the simple reality.

So, we are here today to discuss the hard facts that face all of us. This is not just something that is befalling New England. There are irresponsible, renegade criminal activities taking place on the high seas today. There is a form of pirating that is no different from the pirates of previous years. And the pirating today goes out and seeks simply to bypass the laws, avoid the rules, and reach the marketplace. And we are going to have to take actions, and some of them, I think, are going to have to be serious actions, to protect the interests of future generations, not to mention our own interests today. Senator Stevens.

\section{OPENING STATEMENT OF SENATOR STEVENS}

Senator Stevens. Well, Mr. Chairman, I welcome this hearing, and I understand the frustration that you have just expressed. I would put a footnote on one of the comments you made about the North Pacific pollock. That is, I do believe that the harvest of the 
foreign fishing fleets in our 200-mile zone prior to the Magnuson Act was greater than that going on now, although they were unreported and uncontrolled at the time.

I welcome this hearing because I think it is the first time we will come close to addressing some of the new issues that are going to come out of the revised version of the Law of the Sea Conference documents, and I do have some questions concerning the subjects that you have mentioned as they relate to that new version of the Law of the Sea Treaty.

I welcome these witnesses. I think this is a very vital subject for us to be addressing. And, like you, I hope that we can get back to the subject of the Magnuson Act reauthorization. I think that it is vital for us to address some of the issues that are contained in that bill, particularly the subject of waste which you have touched upon, which is a rather difficult subject for the North Pacific at the present time.

Thank you for calling the hearing. I am sorry to tell you that I will not be able to join you in New Bedford.

Senator KERRY. We will not have any lobsters to offer you anyway. [Laughter.]

Senator STEVENS. I think there might be some other creatures of the sea that we could experience up there anyway.

Senator KERRY. You could indeed.

Senator STEVENS. I do think that is a very necessary hearing, and I look forward to that being completed so that we can get back to the Magnuson Act issues.

Thank you for holding the hearing.

Senator KeRRY. Thank you very much, Senator Stevens.

Senator Gorton.

Senator GORTON. No opening statement.

Senator KERRY. Senator Burns.

\section{OPENING STATEMENT OF SENATOR BURNS}

Senator BURNS. Thank you, Mr. Chairman. I do have a statement. And I am going to approach this in just a little bit of a different way if you do not mind. I thank you for starting this process of gathering information on what we think is a very serious problem.

When I first came to the U.S. Senate we started to address the driftnet problem. Senator Packwood and many of us in the Northwest were concerned about the Northwest salmon. And sometimes we tend to overreact, but I want to come at it just from a little bit of a different angle, because the National Marine Fisheries Service does impact Montana even though we are regarded as an inland State. The salmon recovery efforts have had a tremendous and substantial impact on my State in the Northwest. I believe these concerns are related to our efforts to increase the salmon population in international waters.

I just want to address that species. We tend to forget that we are expending billions of dollars on the Columbia River and its drainage area for the recovery of the salmon. That should be a major undertaking for this Nation, and I would support that to a degree. But we also have to understand that we are also talking about a 
species that is on the endangered species list that you can buy in any can in any store in America.

So, I sometimes have a problem with that.

In May of this year, the NMFS overruled agency biologists and ordered the Corps of Engineers to spill huge volumes of water over the dams in the Columbia and the Snake River Basins to flush endangered juvenile salmon to the sea. This controversial gambit has cost ratepayers tens of millions of dollars in higher electricity costs.

Most scientists agree that it will result in negligible additional numbers of adult salmon reaching the spawning grounds. At worst, this expensive experiment may actually reduce salmon numbers. There is strong evidence that the spills are resulting in higher losses of juvenile fish.

The direct cost of this action has been estimated at more than $\$ 1$ million for each adult salmon that will return to the spawning grounds. Although the administration recently agreed to share some of these costs by repaying them from the Federal Treasury, this action will not compensate Montana homeowners near Libby and Hungry Horse Reservoirs, who now have a vast dry mudflat where water usually is.

The payments from the Treasury will not compensate the weekend recreationists that do not have enough water to launch their boats, nor will they compensate for the dust that fills the air for miles and miles when the wind blows in northwestern Montana. And they will not compensate for the job losses directly or indirectly dependent on water that has been drained from our State for very questionable results.

Payments from the Treasury also will not compensate Montana for the problems that the spill has caused for our own efforts to protect fish populations in our own State. And I would draw attention to the bull trout, a species that has been considered for listing on the endangered or threatened list, although the emergency spills by the Federal Government has robbed Montana of our most important tool of protecting our resource and our own fish, and that would be our own water.

So, Mr. Chairman, I believe that this action by the NMFS is a national disgrace. It has resulted in tremendous cost to the taxpayers, to agriculturalists and farmers and recreationists, sportsmen, fish and wildlife. And as a result of the administration's recent agreement to offset these direct costs from the U.S. Treasury, cost to the American taxpayers may range up to $\$ 30$ million.

Citizens of the Northwestern States and the U.S. taxpayers have every right for adequate, technically defensible justification for this drastic action. The justification has not been provided by the $\mathrm{Na}$ tional Marine Fisheries Service. There has been little consultation with other river interests. There have been few efforts to provide public involvement in the coordination with Congress or existing salmon recovery programs.

And, worst of all, there has been no time for scientific review or biological analysis. Scientific equipment to gather data for the results of this multimillion dollar experiment are not even in place. So, the emergency spill action ordered by the National Marine Fisheries Service is not based on science, it is based on political 
science and the perceived need for immediate dramatic and drastic action to do something to save the salmon regardless of the results.

Mr. Chairman, this week I am joining with my colleagues from the effected States-Senator Craig of Idaho, Senator Gorton of Washington, Senator Packwood of Oregon, and Senator Kempthorne of Idaho-calling upon the Secretary of Commerce, Ron Brown, to require the National Marine Fisheries Service to provide adequate, technically defensible justification for any additional flow requests from the Snake and the Columbia River Basins. We believe that the National Marine Fisheries Service cannot provide this justification-and then request for additional flows should not be made.

So, I am submitting my prepared statement along with this letter for the Secretary in this record.

[The prepared statement of Senator Burns and the letter follow:]

\section{Prepared Statement of Senator Burns}

Mr. Chairman I would like to express my strong concerns with the problems resulting from the National Marine Fisheries Service (NMFS) salmon recovery efforts and their tremendous impact on my state and other states in the Northwest. I believe that these concerns are related to our efforts to increase salmon populations in international waters.

In May of this year, NMFS overruled agency biologists and ordered the Corps of Engineers to spill huge volumes of water over dams in the Columbia and Snake River basins to flush endangered juvenile salmon to the sea. This controversial gambit has cost ratepayers tens of millions of dollars in higher electricity costs. Most scientists agree that it will result in negligible additional numbers of adult salmon reaching the spawning grounds. At worst, this expensive experiment may actually reduce salmon numbers. There is strong evidence that the spills are resulting in higher death losses for juvenile fish.

Direct costs of this action have been estimated to be more than $\$ 1$ million for each adult salmon that will return to the spawning grounds. Although the Administration recently agreed to share some of these costs by repaying them from the Federal Treasury, this action will not compensate Montana homeowners near Libby and Hungry Horse Reservoirs who now have a vast, dry mudflat where water usually is. Payments from the Treasury won't compensate weekend recreationists who don't have enough water to launch their boats. They won't compensate for the dust that fills the air for miles and miles when the wind blows. Payments won't compensate for the lost jobs directly or indirectly dependent upon the water that has been drained from our state for very questionable results.

Payments from the Treasury also won't compensate Montana for the problems that the spill has caused for our own efforts to protect fish populations in our own state-fish including the bull trout-a species that has been considered for listing as threatened or endangered. Through the emergency spills, the federal government has robbed Montana of our most important tool for protecting our own fish-our water.

Mr. Chairman, I believe that this action by NMFS is a national disgrace. It has resulted in tremendous costs to ratepayers, farmers, recreationists, sportsmen, fish and wildlife. As a result of the Administration's recent agreement to offset these direct costs from the U.S. Treasury, costs to American taxpayers may be in the range of $\$ 30$ million. Citizens of the northwestern states and the U.S. taxpayers have every right for adequate, technically defensible justification for this drastic action.

This justification has not been provided by NMFS. There has been little consultation with other river interests. There were few efforts to provide public involvement or coordination with Congress or existing salmon recovery programs. Worst of all, there has been no time for scientific review or biological analysis. Scientific equipment to gather data on the results of this multi-million dollar experiment were not even in place.

The emergency spill action ordered by NMFS is not based on science. It is based upon POLITICAL, SCIENCE and the perceived need for immediate, dramatic and drastic action to do something to save salmon-regardless of the results $\mathrm{Mr}$. Chairman, this week am joining with some of my colleagues from the affected states in calling upon Secretary of Commerce Ron Brown to require NMFS to provide ade- 
quate, technically defensible justification for any additional flow requests from the Snake and Columbia River systems. We believe that if NMFS cannot provide this justification, then requests for additional flows should not be made. I am submitting this letter to secretary Brown for the hearing record.

Mr. Chairman, thank you for allowing me to express my strong concerns with the NMFS salmon recovery efforts and their impact upon my state.

\section{Joint letter From Senator Burns, Senator Craig, Senator Gorton, Senator PACKWOOD, AND SENATOR KEMPTHORNE}

JULY 21, 1994.

The Honorable RoN Brown,

Department of Commerce,

Washington, DC 20230

Dear Secretary Brown: As you know, the Pacific Northwest states have been grappling with the difficult issue of Snake River salmon protection and recovery under the requirements of the Endangered Species Act (ESA). This issue is made all the more difficult because the region is experiencing one of the lowest water runoff years on record within the Snake-Columbia River Basin.

Throughout the state and federal ESA consultations for salmon management our states have taken the position of compromise and support for several recovery measures, even though these measures require economic costs from citizens and offer little direct benefit. State representatives also have supported some flow-related actions, such as the measures identified by representatives of the Northwest Power Planning Council within the "Strategy for Salmon" plan developed in 1992. Each state has worked with the other Northwest states and key federal agencies as both a "good neighbor" and a concerned steward of the region's salmon resources.

More recently, the National Marine Fisheries Service (NMFS) has requested additional flow regimes for the spring and summer season salmon migration as part of the ESA Sec. 7. consultation process. These spills, combined with flow requests have called upon the states of Idaho, Montana and Washington to draft each state's principle recreation reservoirs to levels that affect the scenic, recreational, agricultural and hydroelectric value of these reservoirs. In addition, negative impacts on resident fish and wildlife populations have been documented.

The costs for these additional spills are no longer borne only by Northwest ratepayers and water users because the Administration has recently agreed to offset the costs of measures "beyond" the current biological opinion. Since direct costs to the U.S. Treasury may be in the range of $\$ 30$ million, American taxpayers also have every right for adequate technical justification for the spills.

Your claim that the spills would result in a 5 percent Improvement in salmon sur. vival is very much in dispute. Given the high incidence of gas bubble disease resulting from the spill, we believe that it is very unlikely that that these hoped-for gains will be achieved.

Mr. Secretary, NMFS has done a poor job of offering technically defensible justification for the spill requests. This inability or reluctance to provide meaningful justification for major changes in reservoir and river operations must cease. If NMFS cannot provide meaningful justification for its river operations requests, then it should not make such requests. NMFS must act in an accountable manner. We request that NMFS provide adequate justification for the spill decisions before additional spills are ordered.

Sincerely,

CONRAD BURNS,

U.S. Senator.

LARRY E. CRAIG, U.S. Senator.

SLADE GORTON, U.S. Senator.

DIRK KEMPTHORNE, U.S. Senator.

BOB PACKWOOD, U.S. Senator.

Senator BURNS. And I thank you, Mr. Chairman, for gathering the information on this. Because what we do in marine fisheries does have an effect on upstream and the contributing rivers to some of the problems that you are experiencing. So, this goes much 
further inland than we tend to believe or the public tends to believe.

I thank you.

Senator KERRY. I thank the Senator. I would simply say that the converse is also true. Upstream activities have an enormous impact on New England fisheries. There are 60,000 acres of closed clam flats off Cape Cod today due to nonpoint source pollution. Runoff from oil and gasoline spills, refuse, and development, flows into our rivers and estuaries and remains a serious threat to coastal water quality and coastal resources.

I am very familiar with the Columbia River issues.

Senator BURNS. Actually, Mr. Chairman, we just have basically two species, one is on the endangered species list and one is a candidate to be listed.

Senator KERRY. I understand that. There is a balance there, and you have raised very legitimate issues. I am not questioning at all what you have raised. I am simply saying that we have to understand the converse is also true.

Senator BURNS. Sure. That is exactly correct.

Senator KERRY. Regrettably, too many of our bays and estuaries are dying. Right here in Chesapeake Bay nitrate overloading has resulted in a classic example of an area in jeopardy because of developmental practices.

Mr. Ambassador and Mr. Secretary, thank you for being here with us this morning. Do you want to lead off, Mr. Ambassador? Thank you.

\section{STATEMENT OF AMBASSADOR DAVID A. COLSON, DEPUTY AS- SISTANT SECRETARY OF STATE FOR OCEANS, DEPARTMENT OF STATE}

Ambassador Colson. Thank you, Mr. Chairman. I do have a prepared statement, and if it could be placed in the record I will summarize.

Senator KERRY. Thank you very much. Without objection, the full statement will be in the record.

Ambassador COLSON. I am delighted to be accompanied by Will Martin of NOAA, who is going to address some of the international fishery issues. I think I can say that, based on almost 20 years of experience in the Federal Government working on these issues, the cooperation today between the State Department, NOAA, the National Marine Fisheries Service, and the Coast Guard is the best that it has ever been. And I also think I can say that the channels of communication with the NGO community and the industry, relating to these issues, is as good as it has ever been, and I look forward to hearing the discussion from the second panel this afternoon.

There are many, many issues involved when you just talk about international fisheries. There is a tremendous range of issues that we could talk about, and we really do not have time to do it, so I would like to focus on nine different very specific points.

First, I do think that we can say today that the United States has taken a very strong leadership role internationally on these international fishing issues. We do so because of our concern for the marine environment. We do so because we know that the sus- 
tainability of international fishery resources is necessary for the long-term viability of our commercial fishing industry. And we do so, fully committed to the balance of interests that are contained in the Law of the Sea principles that balance the rights of coastal States and the rights of fishermen to fish on the high seas.

Mr. Chairman, coming back to the point that was just made by yourself and Senator Burns. One of the things that we always have problems with in international fishery negotiations is that we are just focused on allocation issues. And one of the things that we need to begin to do and that we want to do in the Department, in the next year, is really begin to focus on some of these other pollution issues, such as pollution, that affect our fishery resources. And one of the things that the administration has done is offer to host a global conference on land-based sources of marine pollution.

This initiative arises out of UNCED. It was one of the conferences that UNCED called for. We will be hosting that conference here in Washington, DC, in November of 1995. And certainly, we want to tie fisheries into the marine pollution issue because it is so important, just as you mentioned. You can have lots of arguments about allocation of a clam bed, but it is not going to do you any good if you have not dealt with the pollution issues upstream. Otherwise you are not going to have any clams there in the future. This is a big problem around the world, bigger perhaps than it is in the United States. We want to begin to bring a lot of these issues together that in the past we have sort of kept separate.

Second, I do want to mention the driftnet issue. I think we can say that through U.S. leadership we have gotten a real handle on this. We remain vigilant in respect of the moratorium that was adopted in 1992. In the Pacific Ocean I believe we can say that the moratorium is being fully respected. We have had very few situations where we have had some bandit problems, but the countries concerned have been cooperating with us. We have a very good enforcement agreement now with the Government of China that relates to any situation where we might find a vessel that is violating Chinese law on the high seas, dealing with driftnets, to work with the Chinese Government on that kind of a problem. There have only been a couple of cases of this sort over a 2-year period.

We also have a difficult situation in the European area, in the Bay of Biscay and in the Mediterranean. I think it is important as we consider this situation to note that the rules of the governments concerned, the Italian and the French Governments and the European Community, are to respect the U.N. moratorium on driftnets. They respect the length of the net that is required by that moratorium. But at the same time there are problem fishermen. There are rogue fishermen in any country. And these governments may not yet have been able to get a handle on some of the illegal fishing practices that go on in those nations.

The question before us is, Are we working hard enough with those governments? Are we keeping the issue in front of them? And I think we can say that we are and that we are making progress. Mr. Kantor raised this during the G-7 with the Italians, and we are keeping this as a major part of our foreign policy efforts with the Italian and the French Governments and the European Community to make sure that the allies that we have in Europe on the 
driftnet issue are working hard with us to get the unauthorized fishing that is going on there under control.

You did mention the new agreement that has risen out of the Food and Agricultural Organization. We sometimes call it the "Flagging Agreement" or the "Reflagging Agreement." In my view, this is one of the most important global fisheries agreements that has emerged in the last 20 or 30 years. It is an agreement that, if we implement it well, if the international community implements this agreement well, it will do a great deal to resolve the problem of irresponsible fishing on the high seas.

As a general proposition, what this agreement does is simply require states to regulate and control the activities of their fishing vessels on the high seas. And it requires countries, if their vessels are going to fish in a region, that they be party to the regional conservation agreement and the country concerned has a responsibility to ensure that its fishermen act in accordance with the conservation rules. This will take care of the reflagging problem, it will take care of the problem of new fishing vessels, which you mentioned, being flagged directly into flag-of-convenience countries, where those countries have no ability to control the activities of those boats, yet we find them showing up all over the high seas.

That agreement is now before the Senate. There have been hearings held in the Foreign Relations Committee. The administration has transmitted implementing legislation, and I certainly hope-I know that time is short in this Congress, but it would be really a fine thing if the United States could exercise leadership here by being one of the first countries to accept this agreement and bring it into force.

In that regard, I would also like to note that this agreement was just part of an exercise that the Food and Agricultural Organization has taken on to develop a code of conduct on responsible fishing practices. It is not expected, Senator, that this will result in any other binding agreements, but we do think that through this process there is going to be a series of nonbinding resolutions and declarations on a variety of issues of real importance to the international community. It is an area where the United States can take a significant leadership role while at the same time involving a lot of the developing countries that are having a hard time addressing these issues in their own 200-mile exclusive economic zones. It is an area that we want to spend a great deal of energy on.

Mr. Martin is going to be addressing the U.N. Conference on Straddling Stocks and Highly Migratory Species. I would just say that the administration has now made clear its willingness to pursue a binding agreement out of that process. But that does not detract from the difficulty, I think, that we will face in reaching a meaningful agreement on a global basis which is going to be supported by the variety of U.S. constituent interests that are concerned here.

But I am confident to say that we will seek a result that will support and will supplement the key agreements that we have reached in the Donut Hole and in the South Pacific, and that we will not do anything in that negotiating context that would prejudice those agreements in any way. We will certainly be working 
hard in the coming months to exercise leadership in that negotiation to see if we can reach a meaningful agreement that does more than put words on paper. There are a lot of words being spilled in this negotiation right now. The negotiating text is enormously long. It is quite difficult to get a handle on what the obligations are. And one of the things that we in the United States are going to have to do is help pare that down and transform what has been generally a global discussion about fisheries issues into a meaningful international agreement.

Now let me turn for a moment to the new Donut Hole Treaty. This is the treaty that deals with the area beyond national jurisdiction in the Bering Sea. It is at the White House now. It should be submitted shortly to the Senate for advice and consent to ratify. This gives a real content to the duty of states to cooperate on the high seas. This was a long, tough negotiation. It took us 3 years and 10 meetings to put it together, but I think I can say we have got a state-of-the-art international fishing agreement out of this process. It is an agreement for the 21st century. It is going to require 100-percent transponder use in the Donut Hole, it is going to require full observer coverage in the Donut Hole, and it is basically going to let decisions made by the coastal states, and in particular the United States, on conservation issues, translate themselves into the high seas area of that region.

It is going to be, I think, one of the agreements that the international community will look to in the future to say this is the way that it should be done. I am certainly pleased with the effort that our delegation put into it. Both Washington State and Alaska put a lot of energy into that negotiation. We had good participation from both areas, and I think we have got a real good agreement. And again, I know that time is short in this Congress, but if we could get advice and consent to ratify that treaty this year it would again put us in the forefront of bringing this agreement into force.

Certainly, another region of great importance to the United States is the Central and Western Pacific and the tuna agreement that we have out there. This is one of those situations where we are sort of on the other side of the fence. We are not the coastal state, we are the fishing state in the region. One of the things that with the help of the industry we have been able to do is to be very evenhanded in the way we have approached this. The Islanders always look at what the United States is requiring in our zone or with respect to fishing that is going on just outside of our zone, and they want that to translate into what our industry does in that region.

With the cooperation of the industry I think we have been able to satisfy the island governments and just a year-and-a-half ago we were able to reach agreement on a 10-year extension of that agreement which does a great deal for certainty in the industry. This is an agreement that we are, at the State Department, certainly committed to nourishing. It is a good agreement for our industry and it is a good agreement for our foreign policy with the small island countries in this area.

I might say that we are just beginning to recognize, though, the problem that you noted at the outset, Mr. Chairman, which is the increased fishing effort that is going into the South Pacific and 
Western Pacific region. There is probably a doubling of fishing boats, not of U.S. boats but of boats from other countries, that are fishing in the region than there were maybe even 5 years ago. Our experience tells us that that is going to begin to create a real problem in terms of the conservation of the stocks. We have begun a process in working with the other countries fishing in the region and working with the coastal states to begin a process of developing, of addressing, those kinds of problems. We will begin that dia$\log$ this December.

I would also note that Assistant Secretary Winston Lord and I will be going out to the region in another week. One of our central themes will be our willingness to work with the islanders to begin to help them work on the conservation issues of this very valuable tuna resource in the Central and Western Pacific.

Finally, I would like to mention just two items that are a bit of a problem. They are not huge practical problems at the moment but they are problems of principle and inconsistency in our practice.

I have recounted a number of instances where the U.S. position is to work through international organizations and to call upon countries to cooperate and reach agreement. Yet even though the Senate approved the NAFO Treaty for the Northwest Atlantic-in 1983 the Senate gave advice and consent to that treaty-we have not become a party to NAFO, yet U.S. fishing vessels do from time to time go into that region. And certainly, it is our view that if they do that the United States should be party to that regional agreement and U.S. vessels in that area should be fishing pursuant to whatever understandings we have worked out with the other countries concerned. So, we certainly feel that it is important for the Congress to pass implementing legislation for NATO so that we may deposit our instrument of ratification, if it is indeed true that there are people in New England that still want to go up to the Grand Banks and fish there.

Today there are not very many fish in that region. There is a real conservation crisis in the region. The few U.S. boats that have been going to the region have not been able to make a go of it, very easily. But the bottom line here is, Are we going to do what we say other countries should do? Are we going to ensure that our fishermen, when they fish in other parts of the world, fish in a manner consistent with the relevant international conservation organization.

Finally, on a similar point, the Sea of Okhotsk: There is an enormous conservation problem in the Sea of Okhotsk, and I think the Congress recognized this last year. On the Senate side you passed S. 1515 and on the House side a similar bill passed. But somehow or other things did not gel so we did not get a piece of legislation out of it.

It is really important, I think, for our bilateral relations with the Russians, and that is key to a cooperative relationship in the Bering Sea and the North Pacific Ocean, that we ensure that any fishing activity by U.S. vessels in the Sea of Okhotsk takes place in a manner that is consistent with understandings with Russia. It would just be disastrous for us, I think, in a whole range of issues, if we suddenly had a number of U.S. vessels entering that area 
while there is a conservation crisis without any controls imposed upon them through an agreement with the Russians.

So, thank you, Mr. Chairman. There are certainly many other issues that we could talk about, but I would be happy to answer any questions you might have.

[The prepared statement of Ambassador Colson follows:]

\section{Prepared Statement of Ambassador David A. Colson}

I appreciate the opportunity to testify before the Committee on current international fishery conservation and management issues.

The State Department's involvement with fisheries issues dates from the earliest history of the United States. In 1789, Thomas Jefferson, when he was Secretary of State, submitted a report to Congress describing the decline of New England fisheries harvests. Until recently, many have considered the seas to be an inexhaustible source of fish Living marine resources are now known to be under extreme stress. World harvests of marine species peaked at about 86 million metric tons in 1989. The United Nations Food and Agriculture Organization reports that the catch of marine species declined to 82 million metric tons in 1992. Absent concerted efforts to bring about responsible fishing practices, we can expect this downward trend to continue. The fishing power in the world is simply too great; new care must be taken to conserve the fishery resources of the sea so that they can be used sustainably by future generations and play their central role in the marine ecosystem.

As we consider these facts, however, two other points need to be noted: first, since about 90 percent of the world's fish catch occurs in the 200 mile zone of coastal states, much of the responsibility lies with individual countries to conserve and manage the resources for which they are responsible. Second, our awareness of the importance of fisheries to our economies and way of life, and the need to be prudent and wise in our international fisheries management, emerges at the same time that the world is on the brink of a population explosion. Our ocean resources cannot help but come under increasing pressure from this fact alone. We must be very wise in the years ahead to ensure the sustainability of the world's fishery resources.

The Department of State has aggressively pursued an approach over the last several years of taking the initiative in the international community to address fishery conservation and management issues, both bilaterally and multilaterally, with an emphasis on solving high seas fisheries problems. This is consistent with the approach adopted at UNCED, and has proven successful. We have recently concluded several agreements which contribute to the sustainable use of international fisheries and which should be to the long-term benefit of U.S. fishermen. I would like to discuss some of these agreements, and describe other areas which we continue to address.

I am accompanied today by Mr. Will Martin of the National Oceanic and Atmospheric Administration. He will address one of the major international fishery negotiations now under way, the United Nations Conference on Straddling Fish Stocks and Highly Migratory Fish Stocks.

\section{FAO "FLAGGING" AGREEMENT}

On June 28, 1994, I testified, on behalf of the Administration, in support of the Agreement to Promote Compliance with International Conservation and Management Measures by Fishing Vessels on the High Seas (the "Agreement") before the Committee on Foreign Relations. The Agreement was adopted at Rome by consensus of the Food and Agriculture Organization of the United Nations on November 24, 1993.

The Agreement was made possible largely by the initiative of the United States. It represents one critical element of our efforts to bring fisheries conducted on the high seas under greater control in order to protect the marine ecosystem and to ensure the sustainable use of high seas fishery resources over time.

The Agreement rests on the legal framework established in the 1982 United Nations Convention on the Law of the Sea. It builds upon the basic obligations contained therein for States whose vessels fish on the high seas to cooperate in the conservation and management of high seas resources. It seeks to ensure that there is a genuine link between those states and the vessels that fly their flag.

The Agreement addresses a growing threat to the integrity of multilateral fishery organizations. Fishing vessels flying the flag of some States participating in such organizations have increasingly reflagged to non-member States as a means of 
avoiding fishing restrictions that would otherwise apply to them. However, reflagging is only part of a larger problem. A growing number of newly built high seas fishing vessels are registered directly in States that are not members of the major multilateral fishery organizations. The Agreement also addresses the problems caused by this practice.

The Agreement contains two primary objectives: (1) to impose upon all States whose fishing vessels operate on the high seas obligations designed to make the activities of those vessels consistent with conservation and management needs, and (2) to increase the transparency of all high seas fishing operations through the collection and dissemination of data.

Under the Agreement, Parties must:

- ensure that such vessels do not undermine international conservation and management measures;

- prohibit such vessels from fishing on the high seas without specific authorization from the appropriate authority of the Party;

- not issue such an authorization unless it can exercise responsibility with respect to such vessel;

- not issue such an authorization to a reflagged vessel that has previously undermined the effectiveness of international conservation and management measures, unless certain conditions are met (e.g., real change of ownership and control);

- ensure that such vessels are marked in accordance with recognized international standards;

- ensure that such vessels provide to it sufficient information on its fishing operations; and

- take enforcement measures in respect of such vessels that contravene the requirements of the Agreement.

Taken together, these obligations for Parties whose fishing vessels operate on the high seas establish a sound basis on which high seas fishing must be conducted if living marine resources are to be properly conserved and managed.

Implementation of the Agreement by the United States will require new legislation. The Administration proposed such legislation to Congress on July 1 . While we seek Senate advice and consent to accept the Agreement expeditiously, we would not deposit the United States instrument of acceptance until such implementing legislation is passed.

In summary, the FAO "Flagging" Agreement will protect the marine ecosystem and further the goal of sustainable use of fishery resources. The United States, as a member of most important fishery organizations whose measures will be strengthened by the Agreement, stands to benefit considerably from its entry into force.

\section{CENTRAL BERING SEA "DONUT HOLE" AGREEMENT}

On June 16, 1994, representatives of China, Korea, Russia, and the United States signed the "Convention on the Conservation and Management of Pollock Resources in the Central Bering Sea." I was pleased to sign the Convention on behalf of the United States. Japan and Poland, the other participating countries in the preparation of the agreement, are expected to sign the Convention in the near future.

The Convention represents three years of intense negotiations to address high seas overfishing of the pollock resources in the high seas areas of the Bering Sea known as the "Donut Hole." As you are aware, pollock in the Bering Sea is very valuable resource, both economically and as a vital part of the marine ecosystem in the Bering Sea and North Pacific Ocean. Unregulated fishing on that part of the pollock stock which migrates from the U.S. and Russian zones to the high seas "Donut Hole" area is of great concern to us. Vessels of Japan, China, Korea, and Poland began fishing without restraint in mid- to late 1980 s on the pollock stock in the "Donut Hole." The result had a dramatic negative effect on the size of the stock. It also raised serious concerns about possible long-term adverse impacts on ecologically-related species.

In coordination with Russia, in late 1990, we invited the governments of countries fishing in the "Donut Hole" to begin considering with us arrangements for the conservation and management of the living marine resources in the Central Bering Sea. In February 1991, the first of ten negotiating conferences over the next three years was held. Over the course of that time, the Parties agreed to freeze fishing operations (which later was turned into a suspension of all fishing operations), discourage other countries from seeking to fish in the area, conduct cooperative research efforts and exchange information, release any salmon or herring taken as bycatch, and outfit vessels fishing for pollock with position-fixing satellite transmitters. The U.S. and Russia made a number of summit-level statements on the status of the negotiations as they progressed. The result of the negotiations is the "Convention 
on the Conservation and Management of Pollock Resources in the Central Bering Sea." lt is a state-of-the-art fisheries agreement that will establish an international regime which will ensure the long-term conservation and management of pollock resources in the Central Bering Sea.

Under the Convention, harvest levels of pollock in the "Donut Hole" will be based on the best scientific and technical information available. There are strong enforcement and compliance provisions to ensure responsible fishing. Chief among these are the requirements that each and every vessel fishing for pollock in the Central Bering Sea use a real-time satellite position fixing device; each carry scientific observers; and each consent to boarding and inspection by enforcement officials to ensure compliance with the Convention.

These are provisions that, with others, make the Convention a unique, forwardlooking agreement. Representatives of the U.S. fishing industry, government officials, and Congressional representatives strongly supported the U.S. negotiating effort. The regime the Convention creates will aid in ensuring the continued viability of the U.S. pollock industry. It will also serve as an effective forum for closer and improved international coordination of fishery enforcement activities on the high seas of the North Pacific. The benefits to be derived from the Convention will make its establishment extraordinarily worthwhile.

The Administration is preparing to submit the Convention to the Senate for its advice and consent to ratification. I hope that upon receipt from the President, the Senate will give favorable consideration to the Convention and provide its advice and consent to ratification in order that we can deposit the U.S. instrument of ratification and the agreement can enter into force as quickly as possible. Finally, we are prepared to work with the Congress to secure implementing legislation as necessary.

\section{LAW OF THE SEA CONVENTION}

Secretary of State Christopher recently announced the decision of the United States to sign, later this month. a new agreement that will fundamentally revise the deep seabed mining provisions of the 1982 United Nations Convention on the Law of the Sea. Once this agreement is signed, the Administration intends to submit it, along with the Law of the Sea Convention, to the Senate for advice and consent. We firmly believe that the United States should become party to this regime to advance our wide-ranging interests in proper governance of the world's oceans that will be achieved through broad acceptance of the Law of the Sea Convention, as revised by the new agreement.

Like most States, the United States has long accepted the fishery provisions of the Law of the Sea Convention as reflecting customary international law. By recognizing the sovereign rights of coastal States to conserve and manage fisheries within their exclusive economic zones, the Convention has brought most living marine resources under the control of coastal States. The Convention also creates basic obligations for all States to cooperate in the conservation and management of high seas fisheries. These provisions of the Convention have established the very framework within which the United States and others in the international community have reached more specific fishery agreements, usually on a regional basis. The Central Bering Sea pollock convention is a good example of a fishery agreement built on the Law of Sea framework.

\section{CONVENTION ON FUTURE MULTILATERAL COOPERATION IN THE NORTHWEST ATLANTIC} FISHERIES

I would also like to discuss the Convention on Future Multilateral Cooperation in the Northwest Atlantic Fisheries (the Convention), done at Ottawa on October 24, 1978. The Convention established the Northwest Atlantic Fisheries Organization (NAFO), which regulates fisheries on straddling stocks in that portion of the Atlantic. The Convention provides for conservation and management of fish stocks that occur outside national zones of jurisdiction. It also provides a framework for scientific cooperation on fisheries of the Northwest Atlantic Ocean.

The United States has not yet acceded to the Convention. The time has come to do so if we have an interest in the fisheries of this region and if our fishermen are going to fish there. Our policy-on a wide range of international conservation issues-is to participate in regional conservation and management regimes. We make it a cornerstone of our laws and policies to encourage others to do so. Our failure to participate in the NAFO regime for stocks in the Atlantic, which U.S. fishermen occasionally harvest, is inconsistent with our policies to encourage cooperation in international resource management and to ensure the sustainable use of fisheries resources through participation in international management agreements. Our failure to participate also undermines our credibility, both in terms of our support for 
regional fishery management agreements and with regard to our statements of concern for the health of the marine environment and the sustainable use of fishery resources. Major fishing nations, such as Japan, Russia, Poland, and now South Korea, whose vessels fish in both the Donut Hole and the NAFO Regulatory Area, note regularly the inconsistency of our position. For example, we pressed hard to establish a regional regime in the North Pacific to conserve and manage straddling fish stocks, while failing to participate in the regional fishery management organization of the same type for the Northwest Atlantic region.

Fish stocks in the NAFO Regulatory Area off Newfoundland are at all-time low levels of abundance. Moratoria are in effect on many species for stocks both within and outside Canada's EEZ. Canada has mounted extraordinary diplomatic initiatives within NAFO, and through the United Nations, to halt the decline of these valuable fish stocks. Canada has even taken the unprecedented step of declaring that it will exercise "custodial enforcement" over the portions of the rich Grand Bank fisheries which take place in the NAFO Regulatory Area outside the Canadian EEZ. We strongly oppose Canada's threat to take unilateral fishery enforcement actions on the high seas as inconsistent with the Law of the Sea. Canada's action has been effective, however, in deterring reflagged vessels and "stateless" vessels from remaining on the fishing grounds. In fact, on a number of occasions in recent weeks, the only active fishing in this portion of the NAFO Regulatory Area for NAFO-regulated species was being carried out by U.S. vessels.

Some U.S. interests still resist accession to NAFO in the hope that they can fish on NAFO stocks without restriction. Amendment 5 to the Northeast Multispecies Plan has imposed effort limitations on our fishermen in our waters, but we cannot expect that the international community simply will accept a move by U.S. vessels to transfer fishing effort to NAFO waters to fish on stocks of even greater conserva. tion concern. Other countries grow increasingly impatient when our vessels fish on stocks they are sacrificing to conserve. The bottom line is that if U.S. vessels are to participate in this fishery it is incumbent upon our government to join the relevant international conservation organization. We can not argue for conservation and responsible fishing in one place and deny it in another. The House of Representatives has already adopted implementing legislation for NAFO contained in H.R. 3188.

A review of the status of U.S. participation in NAFO follows. On May 3, 1979, the President transmitted the NAFO Convention to the Senate, which gave its ad. vice and consent to ratification on July 27, 1983. The United States has not yet deposited its instrument of accession because no implementing legislation has been adopted to require U.S. fishermen and vessels to comply with the Convention. Thus we are in the unusual position where the Senate approved a treaty more than 10 years ago but we remain outside of it.

NAFO is the kind of organization we encourage others to join. We encourage participation in ICCAT, LATTC, NPAFC and a number of additional regional fishery conservation and management organizations. By remaining outside NAFO, we leave ourselves open to the accusation that we are not participating effectively in an international fishery conservation agreement which regulates a fishery in which the United States has an interest. This is the wrong signal to send if we are really interested in the sustainable use of the fishery resources of the high seas.

It is deeply important if we are to use commercial fisheries on a sustainable basis that all fishermen who fish outside their national zone fish pursuant to rules established through the relevant conservation and management organization for the region.

\section{LARGE-SCALE HIGH SEAS DRIFTNET FISHING}

I am pleased to report to the Committee that the Administration has just submitted its annual report to the United Nations on implementation of the global moratorium on large-scale high seas driftnet fishing. As you are aware, the United States was a major proponent of the United Nations General Assembly resolution on largescale high seas driftnet fishing and the global moratorium on such fishing.

Toward this end, last December we concluded an agreement with the People's Republic of China to ensure effective cooperation and implementation of the moratorium. The Coast Guard is currently carrying on-board one of its cutters patrolling in the North Pacific a PRC enforcement official who would assist in any boarding of a PRC flag vessel using or equipped to use large-scale driftnets. To date this year, the Coast Guard has not detected any large-scale driftnet fishing in the North Pacific. We believe and remain generally pleased that the moratorium is being effectively implemented in the North Pacific. 
With regard to the Northeast Atlantic and Mediterranean Sea, we remain seriously concerned over continuing reports of fishing inconsistent with the moratorium and European laws by some vessels from European countries. We have repeatedly encouraged the relevant governments to take responsible enforcement action to ensure that vessels flying their flag are in compliance with the moratorium. They report that they have implemented more stringent enforcement procedures. We are also seeking independently to confirm reports of activity inconsistent with the moratorium, and will continue to follow this issue closely.

\section{SEA OF OKHOTSK "PEANUT HOLE"}

Mr. Chairman, related to the "Donut Hole," I would like to note that there are occasionally rumors that some U.S. vessels may wish to enter the Sea of Okhotsk off the Russian Far East. There are indications that they may wish to fish in the high seas "Peanut Hole" area of that sea.

The central Sea of Okhotsk "Peanut Hole" area is currently facing a very serious conservation problem with its pollock stocks, not unlike the central Bering Sea "Donut Hole." Vessels of Japan, Korea, China, and Poland have in recent years been fishing without restraint in the "Peanut Hole" on its pollock stocks. As a result, the stocks have reportedly been decimated.

Negotiations initiated by Russia with the fishing countries have been unsuccessful toward reaching an agreement to conserve and manage the stock. Were U.S. vessels to enter the "Peanut Hole," our cooperation with Russia on a broad range of fishery issues would be jeopardized and implementation of the "Donut Hole" Agreement could be frustrated.

However, a bill pending before the Committee would solve this problem. On November 11, 1993, H.R. 3188, the Sea of Okhotsk Fisheries Enforcement Act of 1993, was referred to the Committee, after having been passed by the House of Representatives. The Administration strongly recommends and supports enactment of the bill.

The bill would amend the Central Bering Sea Fisheries Enforcement Act of 1992. It would expand the prohibition on U.S. vessels and nationals from conducting fishing operations in the central Bering Sea, except where such fishing operations are conducted in accordance with an international fishery agreement to which the United States and Russia are parties, to include the central Sea of Okhotsk.

Enactment of the bill would further our bilateral efforts, particularly with Russia, to protect the marine environment and to ensure sustainable fisheries in the central Bering Sea and the Sea of Okhotsk. It would fulfill the intention of Presidents Clinton and Yeltsin, as announced at the Vancouver Summit in April 1993, to expand and improve joint work in the -area of environmental protection, including further development of bilateral cooperation on fisheries in the Bering Sea, the North Pacific Ocean, and the Sea of Okhotsk, including for the purpose of preservation and reproduction of living marine resources.

I urge the Committee to expeditiously consider and take favorable action on the bill.

\section{FAO CODE OF CONDUCT FOR RESPONSIBLE FISHING}

Mr. Chairman, in addition to the FAO "Flagging Agreement," I am pleased to report that the FAO is working to develop a broader International Code of Conduct for Responsible Fishing, which the United States is actively involved with. The Code will address such areas as fishing operations, fishery management practices, fair trade practices, aquaculture development, coastal fisheries and coastal area management, and fishery research.

Earlier this year the FAO drafted the General Principles of the Code. Informal technical consultations are scheduled to continue this fall to finalize the General Principles and to begin considering the thematic areas of the Code in more detail. The FAO Committee on Fisheries is expected to further develop the Code at its meeting next spring. The FAO should conclude its work on the Code and adopt it by the end of next year.

The Code will be voluntary in nature. It should greatly advance responsible fishing everywhere-in coastal areas as well as on the high seas. The United States fully supports development of the Code and will continue to be an active participant in discussions on the Code.

\section{SOUTH PACIFIC FISHERIES}

One of the most fruitful international fisheries agreements to which the United States is a party is the "Treaty on fisheries Between the Governments of Certain Pacific Island States and the Government of the United States of America," popularly known as the "South Pacific Regional Fisheries Treaty." The treaty entered 
into force on June 15, 1988, and in 1992 the United States and the sixteen Pacific Island parties agreed to extend the treaty arrangements through Ju ne 15, 2003. As a result of the agreement, we now enjoy close, cooperative fisheries relations with the nations of the Forum Fisheries Agency (FFA). In fact, the treaty has come to be much more than a fisheries agreement-it is a fundamental component of U.S. relations with the Pacific Island states. It is not an exaggeration to say that the treaty has become a cornerstone of U.S. relations with the countries of the region. The treaty is also of significant benefit to the U.S. tuna industry, since it provides fishing access on fair terms and conditions to nearly 10 million square miles of ocean. The U.S. fleet has done an excellent job of following the rules and making the treaty work from a practical point of view.

While the treaty is of great importance to us, it is basically an access agreement. It does not provide for conservation and management of the region's tuna stocks. Also, there is no multilateral forum where fisheries matters can be discussed with the full range of nations involved in the fisheries. So, there is something of an institutional gap which needs to be addressed. In this regard, a high level multilateral fisheries conference is scheduled to take place in Honiara, Solomon Islands in De. cember of this year. This conference will be the first time that all of the coastal states and distant water fishing nations involved in the region have met together to discuss fisheries issues of mutual interest. If the conference is successful, it will establish some region-wide operational requirements in terms of reporting, observers, transshipment, etc. It will also begin a process of multilateral dialogue on fisheries conservation and management issues. While the islanders are reluctant to establish a formal mechanism for this, there is a need to move toward ensuring that the fisheries resources in the region are not overfished. We are prepared to work closely with the FFA and the Pacific Island States to ensure that the conference is a success.

Thank you very much. I would be happy to try to answer any questions you might have.

Senator KERRY. Thank you very much, Mr. Ambassador. Mr. Secretary, do you have any statement?

\section{STATEMENT OF WILLIAM E. MARTIN, DEPUTY ASSISTANT SEC- RETARY FOR INTERNATIONAL AFFAIRS, NATIONAL OCEANIC AND ATMOSPHERIC ADMINISTRATION, DEPARTMENT OF COMMERCE}

Mr. MARTIN. Thank you, Mr. Chairman and members of the committee. It is a pleasure to be here today to testify along with Ambassador Colson and to discuss with you various international fisheries issues, most especially the United Nations Conference on Straddling Fish Stocks and Highly Migratory Fish Stocks.

I would like to second Ambassador Colson's remarks about the good working relations between the State Department and NOAA in international fisheries areas. It has been a joint objective that we have sought, and I think that it has worked very well recently.

The U.N. conference began in August 1993, and another meeting was held in March of this year. A third session will be held in the last 2 weeks of next month. At the conclusion of the March meeting the countries were split as to the result that they sought. Some favored a nonbinding U.N. resolution or declaration and some favored a binding treaty approach. The current chairman's negotiating text is more oriented toward a nonbinding type of approach. However, in June of this year two informal intersessional meetings were held among some key countries, and as a result of these meetings, the U.N. conference has taken a new turn and now is moving toward a binding international treaty.

Initially, the United States was flexible in supporting the outcome, either as a nonbinding U.N. declaration or as a binding treaty. Recently, however, we have moved to a position of favoring a 
binding treaty and we believe that our move has influenced a number of other countries. We expect the chairman of the U.N. conference, Satya Nandan, to introduce a negotiating text for a binding treaty before the end of the upcoming August session. This negotiating text should then be negotiated in future sessions.

$\mathrm{Mr}$. Chairman, you and your colleagues have spoken about the decline in world fish resources. This decline has been dramatic in some cases where there has been overfishing of straddling stocks such as with pollock as referred to in the Donut Hole and with the fishing in the Grand Banks area off Newfoundland, as well as with some highly migratory species such as bluefin tuna to which you alluded, Mr. Chairman. These problems are difficult because the overfishing activities occur in the unregulated high seas fisheries, those which are outside the exclusive economic zones of coastal nations. This area has traditionally been open to all nations to fish freely, but it has become clear that the traditional freedom of fishing on the high seas must be balanced with the needs and rights of coastal nations. That is the central focus of this U.N. conference.

Let me speak briefly about what the result the United States seeks in this U.N. conference would do. The result we seek from this conference would support and advance the key elements of U.S. fisheries law and practice. We seek to ensure that high seas fishing on straddling stocks would be controlled so that it does not undermine the management regimes of the adjacent coastal nations. We seek to protect our Nation's large and important fisheries for highly migratory species such as tuna and swordfish. The result we seek would support fisheries science by increasing the interchange of detailed fisheries data among fishing countries.

We seek a much stronger cunservation ethic in terms of promoting a precautionary approach designed by NOAA to model state-ofthe-art fisheries management. We also seek to encourage environmentally safe harvest technologies and to promote a multispecies ecosystem approach that protects not only the target stocks but also associated species, including marine mammals and sea turtles.

We seek the use of much better dispute resolution procedures and enhanced compliance mechanisms. We aim to build on the FAO flagging agreement which emphasizes the responsibilities of flag states in monitoring and regulating fishing vessels flying their flag. The result we seek would help in dealing with countries that refuse to join regional fishing organizations. We believe the treaty that will be ultimately developed in this conference will require that in order to fish for straddling stocks or highly migratory species a country must join the regional organization or comply with its regulations. This should give us much greater leverage with nonmember countries in situations such as ICCAT. Finally, our efforts in this U.N. conference strongly support the relevant provisions of the U.N. Convention on the Law of the Sea-a major objective of the United States in these negotiations.

Now, let us understand what the results we seek would not do. Our efforts are not intended to infringe on the domestic fisheries management rights of the U.S. through our regional fishery management councils for fisheries occurring entirely within our EEZ. Achieving our objective in this conference would not require any 
wholesale renegotiation of our existing international fisheries agreements, as mentioned by Ambassador Colson.

We would not harm our distant water fishing interests in terms of their ability to have fair and reasonable access to fisheries resources on the high seas, because we would preserve fair opportunities to share the resources both for coastal nations and distant water nations.

Mr. Chairman, I would also like to add a few remarks about NOAA's support for the flagging agreement. Our personnel assisted directly in the negotiations which produced this agreement within a 9-month period. NOAA also prepared the implementing legislation which was introduced on July 14 in the House of Representatives by Congressman Studds. It is our hope that you, Senator Kerry, will introduce it in the Senate.

This legislation calls for NOAA to assume substantial responsibility for implementing the agreement. We will authorize fishing on the high seas by U.S. vessels and be responsible for receiving and maintaining information on behalf of those vessels. Enforcement of the new requirements on such vessels will be a shared responsibility between NOAA and the Coast Guard.

Thank you, Mr. Chairman. This concludes the summary of my written remarks, which I would ask that you make a part of the record. I would be happy to try to answer any questions that you may have. Thank you.

[The prepared statement of Mr. Martin follows:]

\section{Prepared Statement of Will Martin}

Mr. Chairman and Members of the committee: I am Will Martin, Deputy Assistant Secretary for international Affairs, National Oceanic and Atmospheric Administration (NOAA). I am pleased to be here today along with Ambassador Colson to discuss international fisheries concerns, particularly the United Nations (UN) Conference on Straddling Fish Stocks and Highly Migratory Fish Stocks.

\section{INTRODUCTION}

The UN Conference on Straddling Fish Stocks and Highly Migratory Fish Stocks is moving dramatically toward a binding international convention. I am happy to report that the United States has played a key role in this Conference. We have sought to bridge the interests of both coastal and distant-water fishing nations, and we have successfully introduced many of our key fisheries conservation and management principles into the Chairman's negotiating text.

This convention will play a critical role in resolving future fisheries disputes, like the one we settled successfully in the Central Bering Sea pollock negotiation. All participants in the UN Conference have agreed that their work must be consistent with the United Nations Convention on the Law of the Sea. The work of the Conference thus builds on UNCLOS, on our success in negotiating the Food and Agriculture Organization (FAO) "flagging" agreement, and on our experience in outlawing high seas driftnet fishing. It underlines the fact that fishery management within EEZs (exclusive economic zones) is not enough. But the outcome of the UN Conference will also have important implications for how we manage domestic fisheries in the United States. Let me review the background to the Conference and the issues at stake.

\section{BACKGROUND}

In recent years the world community has become aware of a shocking and inescapable fact: fisheries harvests are declining all over the globe. The harvesting capacity of fishing fleets and their imperative for an economic return have overwhelmed the financial and technical resources and the political will of fisheries managers worldwide. High seas fisheries present particular difficulties, because no one nation has jurisdiction over their management. The theme of sustainable development, amplificd at the UN Conference on Environment and Development 
(UNCED), addresses this crisis in marine fisheries, one of the world's greatest natural resources.

Negotiators of the UN Law of the Sea Convention wrestled for years with the thorny problems involved in managing high seas fisheries. They crafted general rules for certain categories of fish, including straddling stocks (occurring within an EEZ and in the adjacent high seas) and highly migratory species (occurring widely within EEZs and throughout the high seas). The negotiators recognized the traditional freedom of all nations to fish on the high seas, but conditioned that right on the observance of the rights and interests of coastal nations.

But the Law of the Sea Convention did not spell out how coastal nations and distant-water fishing nations should cooperate to manage those high seas fisheries. Regional fisheries organizations have been established in some cases to deal with this management problem, but sometimes they have been unsuccessful because they lacked enforcement clout, dispute resolution mechanisms, and leverage over nonmembers. The situation demands a more comprehensive and binding set of international rules.

The UN Conference on Straddling Fish Stocks and Highly Migratory Fish Stocks was initiated by UNCED in 1992 to elaborate on the fisheries management principles outlined in the Law of the Sea Convention. The UNCED proposal for an international fisheries conference was endorsed by the UN General Assembly in December 1992, and the organizational session for the Conference was held in New York in April 1993. Ambassador Satya Nandan of Fiji was selected chairman. The United States highlighted the importance of non-governmental organizations' participation in the Conference's work, and we have included NGOs on our delegations.

The first substantive session of the Conference was held in New York in July 1993. The United States identified eight key points for the Conference to consider:

- ecosystem conservation and management approaches

- strengthening existing and creating new regional fisheries management organizations

- distinguishing between straddling and highly migratory fish stocks

- managing fish stocks throughout their biological range

- improving the scientific basis for management

- promoting environmentally safe fishing technologies

- strengthening enforcement capabilities

- supporting the FAO "Flagging" agreement (FAO Agreement to Promote Compliance with International Conservation and Management Measures by Fishing Vessels on the High Seas).

Ambassador Nandan prepared a draft set of guidelines that incorporated most of the U.S. points. However, his text did not resolve a nu mber of important issues.

The second session of the Conference was held in March 1994. At that time, virtually none of the major distant-water fishing states was interested in negotiating a treaty; they preferred a non-binding statement of principles. At that session, the United States indicated flexibility on the issue of treaty versus statement of principles and submitted a set of principles that further developed the points we raised at the first session of the Conference. The purpose of these principles was to clarify and implement the relevant provisions of the UN Convention on the Law of the Sea. These principles also promoted in the international arena key conservation points drawing from U.S. domestic fisheries law under the Magnuson Fishery Conservation and Management Act.

Following negotiations, the Chairman prepared a revised negotiating text on March 31. This text has been the subject of two inter-sessional meetings held this June, one in Brussels and one in Buenos Aires. The United States moved from its position of accepting either a treaty or a statement of principles to a position favoring a binding treaty, and our move has influenced a number of other countries. The general conclusion of the Buenos Aires meeting was to move the UN Conference toward a binding treaty. This approach will be presented at the forthcoming session of the Conference to be held in New York at the end of August. While there is still much to do, we are taking a leading role in assuring that important principles of fisheries management and conservation are developed in this Conference as effective and binding international standards.

\section{SUBSTANTIVE INTERESTS}

A central tension in these negotiations arises from the different interests of coastal nations and distant-water fishing nations. Reconciling these disparate interests is a challenge for the United States, since we are a nation with extensive coastal fisheries and with important distant-water fleets. The international community must harmonize these interests, because they affect critical environmental and eco- 
nomic concerns-the conservation and long-term sustainable management of renewable marine resources throughout their biological range.

The U.S. position in the UN Conference has been to promote regional fishery organizations as the appropriate fora for resolving these interests. This Conference is setting the parameters for settling disputes among coastal nations and distantwater harvesting nations by requiring all of them to become responsible managing nations and to comply with regulations established by these regional organizations.

There are a number of fish stocks of interest to the United States that will be affected by the UN Conference. Examples include:

\section{Straddling Fish Stocks}

Central Bering Sea Pollock (Donut Hole)-Convention on the Conservation and Management of Pollock Resources in the Central Bering Sea

Northwest Atlantic Groundfish (Grand Banks)—Northwest Atlantic Fisheries Organization (NAFO)

\section{Highly Migratory Fish Stocks}

South Pacific skipjack and yellowfin tuna-South Pacific Tuna Treaty

South Pacific albacore (tuna) - no treaty or organization

Western and central Pacific tuna and tuna-like fishes-domestic fisheries under the jurisdiction of the Western Pacific Fishery Management Council

North Pacific albacore (tuna)-discussions for several years on scientific cooperation

Eastern Tropical Pacific tunas-Inter-American Tropical Tuna Commission (IATTC)

Atlantic Tunas and tuna-like species-International Commission for the Conservation and Management of Atlantic Tunas (ICCAT)

\section{INTERNATIONAL RELATIONSHIPS}

A successful result at this Conference will have important implications for many existing and future regional fisheries conservation and management organizations and arrangements. But it also has critical and particular importance to our allies throughout the world.

For Canada, as well as a number of other coastal nations, the issue of straddling stocks has become a key domestic and foreign policy issue. We strongly oppose Canada's recent unilateral enforcement action in high seas areas of the Northwest Atlantic. But we must work with our Canadian friends to ensure an equitable resolution of the issues of Northwest Atlantic groundfish. This Conference provides the potential for avoiding such disputes in the future and for protecting the legitimate interests of coastal lishing nations. If this Conference produces the type of result we expect, Canada will not be forced to watch their Atlantic groundfish stocks ravaged by foreign vessels which do not heed the conservation rules adopted by NAFO.

For the European Union, Japan, China, South Korea, Poland, and Russia, this Conference raises the potential of additional requirements for operating in high seas fisheries. These fisheries are important to their domestic and international interests. They seek assurances that a coastal nation cannot arbitrarily or discriminatorily exclude them from fishing on adjacent high seas for a straddling fish stock.

Central to this Conference will be finding a way to balance these two sets of interests. We believe that the Conference's emphasis on state-of-the-art fisheries management, flag state responsibility and cooperation, and regional fishery conservation and management organizations and agreements will enable all participants to embrace responsible management principles.

\section{WHAT THE RESULT WE SEEK WOULD DO}

The result we seek from this Conference would support the key elements of U.S. fisheries law and practice.

The result we seek would strongly support the Central Bering Sea Convention and positions we have taken on other straddling stocks. It would ensure that high seas fishing on straddling stocks would be controlled, so that it does not undermine the management regimes of the adjacent coastal nations.

The result we seek would help protect our nation's large and important fisheries for highly migratory species such as tuna and swordfish. These fisheries can thrive only if the entire biological range of these species is considered in conservation and management arrangements.

The result we seek would support fisheries science by increasing the interchange of detailed fisheries data among fishing countries. NOAA designed the strong minimum data standards already agreed to in principle by the UN Conference and in- 
cluded in the Chairman's negotiating text. The result we seek would also enhance the position of regional fisheries organizations in terms of their access to wider scientific information.

We seek a much stronger conservation ethic in terms of promoting a precautionary approach designed by NOAA to model state-of-the-art fisheries management. We played a critical role in the UN Conference's working group on this issue, recommending that distinct management reference points guide fishery conservation and management decisions. We also seek to encourage environmentally safe harvest technologies and to promote a multi-species ecosystem approach that protects not only the target stocks but also associated species, including marine mammals and sea turtles.

We seek the use of much better dispute resolution procedures and enhanced international enforcement and compliance mechanisms.

We aim to build on the FAO "flagging" agreement, which emphasizes the responsibilities of flag states in monitoring and regulating fishing vessels flying their flag. And we are participating in the complementary FAO initiative on developing a Code of Conduct for Responsible Fishing, which involves topics from aquaculture to coastal zone management, as well as fisheries operations. This initiative will be continued this fall in Rome.

The result we seek would help in dealing with countries that refuse to join regional fishing organizations. They will be required to either join or comply with the regulations of these organizations.

Finally, our efforts in this UN Conference strongly support the relevant provisions of the UN Convention on the Law of the Sea, a major objective of the United States in these negotiations.

\section{WHAT THE RESULTS WE SEEK WOULD NOT DO}

Our efforts are not intended to infringe on the domestic fisheries management rights of the United States, through our regional fishery management councils, for fisheries occurring entirely within the U.S. EEZ.

Achieving our objective in this Conference would not require any wholesale renegotiation of our existing international fisheries agreements. In fact, achieving our objective would give us ammunition in our efforts to strengthen some of these agreements. It is true that over time we would need to examine each of our international fisheries conservation and management agreements to determine the extent to which the new standards we create in this Conference are already met. Where these standards are not met, we would have to work with our partners to enhance those agreements.

We do not seek to generate a new over-arching international scientific or management bureaucracy. We would rely on existing regional fisheries organizations, strengthening them where -necessary, and promoting the building of new arrangements only when necessary.

We would not put our fishing vessels at the mercy of foreign fisheries enforcement, since the primary source of enforcement proposed by the UN Conference lies with flag states. Fishing vessels that play by the rules will be judged by their own countries. But vessels that do not, and whose flag states fail to exercise their responsibilities, should be subject to strict international enforcement.

We would not harm our distant-water fishing interests in terms of their ability to have fair and reasonable access to fishery resources on the high seas, because we would preserve fair opportunities to share the bounty of the ocean, both for coastal nations (including developing nations) and distant-water fishing nations. The obligation to enter into consultations with coastal and other distant-water nations to manage these fisheries is one that the United States has consistently accepted and pressed on other countries.

These UN Conference negotiations will not solve all the problems of the ocean and the communities that depend on them. But this Conference is the best route forward.

\section{CONCLUSION}

In the long-run, our fishermen are better served by binding agreements with our international partners regarding straddling stocks and highly migratory stocks, which:

- incorporate the best available science but do not shy from conservation for the long-run in the absence of a perfect scientific record;

- protect the ocean environment and the long-term sustainability of ocean resources; 
- promote effective compliance and enforcement with international fisheries regulations and thus provide a level playing field for our fishermen;

- provide for transparency and for participation by industry and nongovernmental organizations; and

- promote the long-term profitability of substantial public and private investments in fishing.

We have argued in the formal and informal meetings of the UN Conference that coastal nations and distant-water fishing nations must work together to deal with these resources common to EEZs and the high seas. These negotiations are an exercise of our rights and our responsibilities; their successful result would encourage the kind of responsible fishery conservation and management arrangements the world needs.

Thank you Mr. Chairman. I would be happy to answer any questions.

Senator KERRY. Thank you very much, Mr. Secretary. Your remarks will be made a part of the record in full, as if read.

Let me ask you both, at the end you took pains to say that our international fisheries efforts will not infringe on fishing rights in coastal areas and the ability of the management to make choices, nor on distant-water rights, et cetera, et cetera. If it does not infringe a little bit, what is it going to accomplish?

Mr. MARTIN. I think the infringement that I was referring to was the infringement on the prerogative of management within the EEZ of resources that are exclusively within that EEZ. As to straddling stocks and highly migratory stocks that are the subject of the conference, there will, of course, be some responsibilities.

Part of the tension of the negotiations has been to determine whether these responsibilities will be imposed exclusively within the high seas, or will be shared between the high seas and within the EEZ's. It has been the position of the United States in these negotiations that the straddling stocks and highly migratory species should be managed throughout their range, so that it would be a responsibility both within and without the EEZ, not only on the high seas, but also with the coastal nations. Some of the nations within this negotiation have resisted that concept.

Senator KERRY. We can understand the resistance in terms of coastal sovereignty-we see it here, we see it there. What do you think it is going to take to break through the resistance and begin to achieve a consensus about the need to move to a binding regimen more rapidly than we appear to be? What will it take to perhaps eliminate some of the tensions that exist, which I think are based on very parochial, narrow interests usually, beginning with economic interests?

Mr. MARTIN. Senator, I think that the key issue is the one that I have just referred to, the so-called compatibility issue, and I do think that significant progress was made on that issue in the informal meeting in Buenos Aires this past month. If we can solve that issue in a way that provides for an effective and meaningful regulatory scheme throughout the range, then I think that we will have solved the problem and be on our way to achieving a binding treaty.

One of the reasons that we have now moved toward a binding treaty is our confidence that we are on a track that might lead to a meaningful and substantial document, and not just, as Ambassador Colson was referring to in his statement, a lot of words.

Senator KERRY. Do you believe that that document will deal with reduction of effort sufficiently? 
Mr. Martin. It is hard to predict. I do not see that so much in the cards.

Senator KERRY. If there is not a reduction in effort, will there be anything substantive?

Mr. MARTIN. I think the elements that will deal with a precautionary approach and the setting of targets and thresholds, at which point, then, you do reduce effort, would be the way that it will be addressed.

Senator KERRY. Well, the question really is, Is it too tepid? Is it just too diplomatic-too business-as-usual? My concern is, as we approach these things - every nation merely raises its head. Look at the struggle we had recently with France over fish exports-this is going to replicate itself all over the world. It is going to happen, correct? If we bounce around on a continuing basis, year to year, acceding to these narrow parochial expressions, which are absolutely predictable and unavoidable, we are not going to confront the fundamental issue, are we?

If you can reduce the fleets of Norway and Europe and Iceland by 40 to 50 percent and still fish the current level, we have got a fundamental problem. What is there in this that deals with the fundamental problem?

Mr. MARTIN. In terms of reductions of fleets, I do not think we have elements in there at the current time which would specifically address that.

Senator KERRY. So, we are really dancing around the fundamental issue. We are going to go through the motions of all of these international meetings, all of this discussion, and we are not going to confront the fundamental issue, which is that the world's fishing regimen is inadequate to meet the current crisis. It is particularly inadequate if we are forced into these compartmentalizations, 200 miles here, 200 miles there. We are going to deal with the tuna over here, we are going to deal with this over there.

This is an ecosystem. These fish are eating each other and eating other fish, and they swim from one place to the other to eat. If we do not recognize this, and if we do not learn more and quickly make some assumptions about their role in the ecosystem, and what we are doing in the process of harvesting them, it seems to me that we are just not doing enough to address global fisheries issues.

This is not even Sisyphus pushing the rock up the mountain. It is worse. We are not on the mountain. Am I wrong? Tell me. Maybe I am just dead wrong in my assumptions.

Ambassador Colson. You are not wrong, Senator. I do think that the code of conduct that FAO is working on will be addressing effort issues. The flagging convention does in a sense address effort, because we are talking about the practice that has emerged in the world of fishing vessels that are flagged in a particular country reflagging to another.

We have started the process of trying to control that sort of transfer of effort away from responsible behavior to irresponsible uncontrolled behavior. We have not gotten there all the way yet, but we have begun that.

I think the other thing that we are going to find is that you are only going to be able to get at some of these issues by working on 
a regional basis. We have gotten a solution in the Donut Hole, because in essence what has happened because of the way that we negotiated that treaty is that the countries that had large fishing operations there have basically had to begin to encourage some of their industry people to leave business. They have been buyingGovernments have been buying up boats.

It is also true that that is the focus of our concern in the Western Pacific. It is the increase in the number of vessels, and the fact that more and more effort is put in there. We can anticipate that there is going to be a conservation problem, and we are, at least on that issue, in that region, we are in front of a crisis, and we are going to be working hard on that.

But one of the problems in negotiating in a U.N. global forum, as you know, things begin to-

Senator KERRY. I understand that. It is very, very chaotic when you get more than 100 nations trying to play at the same forum. I am not suggesting that you should not move and take the opportunities that you can get as you go along. That is not what I would suggest, and I am all in favor of trying to reach your compartmentalized effort, et cetera.

What I am suggesting is that those efforts are taking place without addressing the larger, more significant issue of overcapitalization. Without significant pressures forcing people to confront a larger reality down the road, all we seem to be doing, at least in my view, is reaching too much for these individual efforts. Whether it is the Bering Sea or Pacific salmon, we are approaching international fisheries management without the view to the larger confrontation and without significant enough pressure, I might add, for countries to try to cope with this larger picture.

Mr. Martin. Senator Kerry, one of the things that is significant about the document we are working on is that it will introduce international conservation rules, and hopefully, with the application of these international rules, the fishing effort will have to be reduced. Perhaps at that point market forces can come into play and will effect the reduction in capacity to which you referred. It will be an indirect effect, but it is not being directly addressed in the document.

Senator KERRY. Of course, the precautionary principle developed at the UNCED conference in Rio de Janeiro might not allow you to wait for the market. The market will indeed react, prices will go up, you will have a diminished supply. There will be a traditional supply-demand curve response.

We have a Commerce Committee fly here that is only attracted to the person speaking, so if any of you are interested in catching this fly, all you have to do is open your mouth and say something and it will conveniently take off. It is true. You noticed, Ambassador. [Laughter.]

I think it is the vibrations.

Ambassador Colson. Is it a Massachusetts greenie?

Senator KerRY. I think that we need to figure out how to elevate overcapitalization concerns to a higher level at the negotiating table.

I think you are going to conceivably be behind the curve with the amount of fishing taking place, the amount of capital that is al- 
ready out there invested in these vessels, and no one, as we have learned in our experiences in New England or whereever it is, no one wants to be the first to bite the bullet.

They are going to wait until there is something that forces them to bite the bullet, and then, indeed, people begin to disinvest, or do the buy-backs, sell-backs, or whatever, but until there is that pressure to confront it, everybody is going to say, "Well, I am going to get my last fish," and then you may just wipe out the chance for recovery.

I think probably we will reach that crisis level where nobody is going to be fishing for a while. We will do on a magnified scale what we did with striped bass or with other species, until they come back, but God knows-we do not even know whether the ecosystem will support rebounding fish stocks. One species may at that point be so dominant that another one simply never comes back. We are dealing with the unknown here, and because we are, we ought to invoke the precautionary principle and be more careful faster.

Ambassador Colson. Senator, if I might just add a comment, it is a question of human resources, almost, in our work. One of the things we want to try to do is do a better job, particularly with some of the nontraditional fishing countries, because while we have had a relationship with the Japans, the Koreas, the Taiwans, and the European countries over the years, what we are seeing is that as those countries begin to engage in more responsible fishing behavior, that a lot of effort is shifting into other countries that have not traditionally been major high seas fishing countries. For instance, the expansion of effort in the Western Pacific is largely Chinese and Indonesian and Filipino, which are countries that we have not had the bilateral relationship on fisheries that we have had with some of our traditional partners in this area.

One of the things we will do, as we have the resources to do it, is begin to make those connections. It is very important, particularly, I think, with respect to China, to begin to have a dialog with them on this kind of an issue, because if they begin to go down this road it is going to be very hard to pull them back.

Senator KERRY. I agree completely with that. It should not, however, be a question of resources for us, because of the urgency. We have folks in the Agriculture Department who could be transferred to work on fisheries issues as the number of farmers goes down. We are just not allocating our resources very effectively.

Senator Stevens.

Senator STEvens. Thank you, Mr. Chairman.

Mr. Ambassador, under part 15 of the Law of the Sea Treaty draft, as I understand it, any dispute concerning interpretation or application of the Law of the Sea Convention shall at the request of any signatory be submitted to compulsory dispute settlement under one of three tribunals, or panels. They are set forth in the draft, as I understand it.

Under all three of these, the decision of the tribunal or panel would be final, and could not be appealed, according to this draft.

Now, I am told the administration believes that our existing agreements, such as the Bering Sea Donut Agreement that you mentioned, the North Pacific Anadromous Stocks Convention, or 
our driftnet action by the U.N., are consistent with that Law of the Sea Convention, but I have got to ask you, do you believe that a country could use one of these dispute settlement procedures of the Law of the Sea to undercut the agreements?

Our decision that they are consistent would not be binding on any panel or tribunal. Is that not a decision that would have to be made by the tribunal or panel, and they could decide contrary to our interpretation, and in effect destroy our agreements? Do you disagree?

Ambassador Colson. Well, Senator, I suppose it is always possible for someone to use a court in the United States or an international dispute settlement issue to advance something that is contrary to what the United States or a particular individual believes. So, hypothetically, certainly arguments could be made by someone to say that the donut agreement or the driftnet agreement is inconsistent with international law. I certainly do not think that they would prevail in that kind of an argument.

The dispute settlement provisions in the Law of the Sea Convention in the fisheries area, they are bifurcated. In respect of someone challenging the fisheries management practice of a country within that country's 200-mile zone, all that can occur is for there to be a compulsory conciliation process. There is not a binding result. I do not believe that there is anything that would happen that would infringe upon U.S. domestic authority management authority out of the Law of the Sea Convention.

Senator STEvens. I am not covering the EEZ. I am covering the agreements that we have reached with other nations such as the Central Bering Sea agreement. That agreement covers the high seas.

Ambassador Colson. Yes.

Senator STEVENS. That area is beyond the 200-mile limit of either Russia or the United States. It is my understanding that, if these tribunals are appointed, the signatory will be able to nominate only 1 or 2 of a 21 -member panel. These panels do not have a tradition of deciding in favor of the United States. They have been basically in favor of the high seas fishing nations.

Now, we have an agreement with Russia. Basically, the Central Bering Sea agreement came about because of pressure from the United States and Russia. It was not really acceptable to some of the high seas fishing nations, but I think they understood our position. We declared a moratorium before we had the agreement, as a matter of fact.

I do believe we have got to look at the ability of nations such as ourselves and Russia and the nations of the North Pacific to make an agreement to protect our stocks.

We have done that in the North Pacific. We have said, we are laying down these rules. We are agreeing, and any nation that takes us on is going to take on us in a military way. I mean, we really asserted control. We let the Navy and the Coast Guard enforce those agreements.

Now, why would we enter into a Law of the Sea Convention that would submit our existing agreements to change with only $1 \mathrm{mem}$ ber, or maybe at the most, 2, of a 21-member panel from the United States? 
Ambassador Corson. Senator, I am quite familiar with the Law of the Sea, but also, I have been the negotiator for many of these North Pacific agreements-I simply do not believe that there is any risk at all of these agreements being opened up by an international dispute settlement panel.

Senator STEVENS. Well then, why did you not just except them from that process?

Ambassador Colson. Unfortunately, that Law of the Sea Convention, most of it was drafted back almost 15 years ago, and it does not provide for reservations.

Assuming that the process goes forward, and the convention and the amending agreement on deep seabed mining is submitted to the Senate by the President, there are many questions that we will have to go through carefully as to what the U.S. position and interpretation of various provisions may be in the course of the Senate's consideration of that treaty.

Senator STEVENS. What about driftnets?

Ambassador Colson. Senator, if there was a person-if there was a fishing operation now that began, a high seas driftnet fishing operation-

Senator STEVEns. Such as in the Mediterranean right now?

Ambassador CoLson [continuing]. Or such as another country opening up a fishery in the Pacific. Right now we simply have the threat of trade sanctions as the tool that we use to enforce our point of view in these situations. If we had international dispute settlement with that country, we could bring that country to court. We are looking at this very defensively.

I think our interests will be served on high seas fishing to be able to go out and ensure that these agreements are abided by, that we will be able, if some other country comes in and starts fishing in the Donut Hole, and they are not part of the agreement. We may use the Coast Guard, but we will also have an option to look at an international dispute settlement. We can take them to court, and they will be violating the rules. They will be violating international law.

If somebody started violating the driftnet resolution, I am confident that an international tribunal would uphold a U.N. resolution providing for a moratorium on driftnet fishing. We would win that case.

So,I suppose there are downside risks to dispute settlement, but there are also upsides to this, and it is something that the Senate, as it looks at the whole convention, is going to have to consider.

Senator STEVENS. I remember the many times I went to the Law of the Sea negotiations. Senator Magnuson sent me almost every year, and we raised the question 15 and 20 years ago.

The question was whether we should submit to a new concept of the Law of the Sea that would override existing protection mechanisms that were in place-such as we now have for driftnets and in the Central Bering Sea.

All of the things we have done to protect the North Pacific are at risk under this new concept of the Law of the Sea. They are measures we have done since the Law of the Sea was drafted. I think the administration better get ready for the fact that those of us who helped put such agreements in place are going to oppose 
the Law of the Sea until it is explicit in terms of protecting the agreements we already have in place. We need to assure the continuation of the vast fishery resources of the North Pacific.

Let me move on to another subject. We have seen television cove: age of the Italian and French driftnet fishing vessels in the Mediterranean. You said we may use the Coast Guard. We did use the Coast Guard the first time we saw a Chinese vessel with a driftnet in the North Pacific. I do not think there is any "may" about it. We have instructed the Coast Guard. I believe we do enforce that the driftnet moratorium in our waters, the waters in which our U.S. fleets operate.

I understand there has been no such action in the Mediterranean. On Saturday we got word that 60 Spanish fishing vessels attacked French tuna vessels that were using driftnets in excess of the limit allowed under the U.N. moratorium. What are we going to do about assuring that the driftnet moratorium is not eroded in waters in which we have not traditionally used the Coast Guard? Has the administration been involved at all in documenting the illegal driftnet usage in the Mediterranean?

Ambassador COLSON. Senator, I think I can say with some vigor that the administration has been on top of this throughout. We are dealing with the problem of illegal activities by fishermen that are vioiating the rule of their own country. The French fishermen are violating French rules and the European Community rules. The French Government is not complicit in this, just as the Italian Government is not complicit in the fact that there are some Italian fishermen that may be violating the rules.

Now, there are questions about the amount of, or about the credibility of some of the evidence that is being brought forward. There are a lot of political allegations being made in this, and one of the things that the administration wants to be sure of, if we go forward to take the next step under the 1992 Driftnet Enforcement Actwhich would start the process leading to trade sanctions-is that we have good, clear, clean evidence that is credible, and not just allegations coming out of some of the European press about what is going on, or allegations coming out of some of the other press that is interested in this issue.

Senator KERRY. If one of you would yield just for a minute, it is my understanding that we have launched an investigation; have we not?

Ambassador Colson. Yes, and we are keeping on top of it. We are using our law enforcement assets.

Senator KERRY. When did we launch the investigation?

Ambassador COLSON. I think it has been an ongoing investigation.

Senator KERRY. Have we ascertained that there are about 700 Italian vessels using driftnets in the Mediterranean?

Ambassador CoISON. Senator, that number is used, and it is an old number. It is a number that is premoratorium. The question is the length of the net. We use driftnets in the United States. The viluestion is, are they shorter than 2.5 kilometers long?

Senator KERRY. Greenpeace has asserted that there are over 700 vesseis currently using driftnets to fish for swordfish in the Mediterranean. This is current. 
Ambassador CoIson. But I do not think, Senator, they say that all 700 of those boats are using nets that are greater than 2.5 kilometers.

Senator KERRY. There is no certainty that some of them are not. Ambassador COLSON. I do not doubt for a minute that there are fishermen that are breaking the rules in Europe or in the United States.

Senator STEvens. In the United States?

Ambassador ColsoN. I believe that we probably have some fishermen in the United States-not driftnets, but that break rules.

Senator STEVENS. No, I am talking about driftnets.

Ambassador Colson. And the rules in Europe on driftnets are the same as the rules in the United States, and the question is, how vigorous are these governments being in enforcing these rules, and are they getting the job done. I think that we can demonstrate that there is progress being made. Now, how fast are they getting it done?

This incident a week ago, it brought about an immediate meeting in Brussels. It brought about an agreement between the French and the Spanish Governments on how they are going to monitor and enforce the rules in that fishery.

Senator KERRY. Let me just interrupt you for a moment. This is a report on large-scale high seas driftnet fishing in the Mediterranean from Greenpeace in November 1993, and they say they have documented extensive violations of the U.N. General Assembly resolution by the Italian swordfish fleet in the Mediterranean. They have been operating in violation of the European regulation which prohibits EC vessels from using driftnets in excess of 2.5 kilometers of net. The regulation has been in effect since June 1, 1992.

They say that there are approximately 720 Italian driftnet vessels which continue to use nets averaging 10 kilometers in length within the territorial waters and the international waters of the Mediterranean. Now, this is as of November of last year. This is what I mean by saying that we are kind of washing around this stuff.

Senator Stevens. But, Mr. Chairman, that was updated Saturday with a report of a new conflict between the Spanish fleet and the French fleet.

What are we doing about trying to get an enforcement mechanism like the Coast Guard in areas like the Mediterranean? Maybe we should take some action through NATO and ask that there be an enforcement group established over there. We are providing it for the North Pacific. Why should not some other nation provide it for the Mediterranean?

Ambassador Colson. Well, that is a new idea, Senator. I do not think we have thought about trying to promote an enforcement capability in Europe.

We have been working hard with the European Community to get them to be more vigorous in their enforcement of these rules. We have been working hard with the Spanish that have the same point of view as we do, and they are calling attention to the violations that they see, and we have been on top of this issue with the French Government and the Italian Government since it became clear that both the Italian and French fishing situation might be 
a probiem, but I do not-I really do not believe, Senator, that the 700 number is a good number in terms of the length of the net.

Senator STEVENS. We moved with just one driftnet vessel, the Chinese vessel-just one. I do not think we need 700 confirmed. All we need is one. If we have one confirmed driftnet vessel that exceeds the allowable limit in use in the world under the moratorium, I think we ought to tell the U.N. we are prepared to help enforce that moratorium.

We sought the moratorium. It was our idea. It is one of the great achievements of the U.N., as far as I am concerned. I am disturbed that we are getting increasing reports of violations in other parts of the world. If driftnets seep back into general usage, I think they will come back into the Pacific and then into the North Pacific.

I think we should move-I will personally take it up with the U.N., with NATO people when we are there in September. I do think that we have to get some enforcement mechanism in the oceans of the world to ensure that those driftnets do not come back, and I think we should be very, very tough about it, too. In days gone by, we have towed them to the shore and sunk them, and I am for some really tough enforcement of vessels that use driftnets.

Senator KERRY. Let me say to you, I could not join more strongly with my colleague. We joined together originally to try to ban driftnets. This is what I am talking about. We have mouthed all the words about the new paradigm and all the new tensions in this postcold war world, but we do not seem to back it up with force.

The fact is that if we are going to say this is the new area of tension, this replaces arms control-and it really does-we are going to need to do something about it. The fight now is not who is aiming missiles at each other, it is who is stripping away limited resources and behaving in a predatory fashion. If we are not willing to be very tough in the enforcement of this, I absolutely guarantee you we are inviting people to simply chase the dollar, or the franc, or the yen, or whatever, and that is what they are going to do.

The economics of this are very, very real, and unless people are forced by some internationally sanctioned enforcement mechanism, it is just not going to happen, because the economics are too strong. There is too much money invested, too many mouths to feed, too many parochial interests at stake.

We saw that happen to our fish when they were landed in France. We see it in these fleets that are fighting with each other. We see it in our fishermen in Maine and Massachusetts, and we are struggling with the Canadians over the question of the sense of inequality in agreements that have been reached. I think it is only going to get worse before it gets better, and we have to secure an enforcement mechanism.

Senator STEVENS. I have one other question, Mr. Chairman, if I may.

I understand from your statement, Mr. Ambassador, that the administration has changed its position and will support a binding agreement in the U.N. Conference on Straddling Stocks and Highly Migratory Species. While this may have some benefits in the past we have been negotiating a nonbinding agreement. What bothers me now is that if we had been negotiating a binding agreement all 
along, we have have sought protections and details that we have not sought as part of the nonbinding agreement. Now, will we seek to add the protections that should be in this binding agreement in the August negotiations? I am particularly concerned because the Bering Sea agreement was a negotiation to protect the pollock stocks and I would not like to see us entering a binding agreement that undercuts existing conventions, such as the Bering Sea convention. Can you tell us what is going to be your goal for the August negotiations?

Ambassador Colson. Let me ask Mr. Martin to address that more specifically. But as I mentioned earlier, I will guarantee you that we will not bring you a binding agreement that undercuts the donut agreement. That is certainly not in our interests.

To the extent that this global U.N. agreement will touch upon issues that are implied or within the donut agreement, I think that they will be entirely consistent with the donut agreement, or that they will supplement and help add on to other principles that maybe we were not able to negotiate in the donut agreement, but that will add to, maybe stronger enforcement provisions, or something like that, that will help us additionally in the Donut Hole area.

Let me ask Mr. Martin to speak to that.

Senator KERRY. Mr. Martin.

Mr. MarTin. Senator, I would second what Ambassador Colson is saying, and I would also point out the current state of the document. Currently, we have one document, which is the chairman's negotiating text. It is neither a treaty nor a nonbinding document, although it is really drafted more toward the nonbinding shoulds and ought-tos rather than the must type of imperatives that you would find in a treaty.

The move now will be in August to produce a new negotiating text for a treaty. We think that will occur after the first week of the session, so we do not have anything at this time to make the comparison to which you are referring. There have been some discussions among countries, and one of the things that we have been very concerned about is that our industry and environmental groups who are most interested in this outcome have not been able to be a party to these discussions, so what we see unfolding in the future would be the production of a negotiating text of a treaty and a nonbinding resolution to accompany that. That will occur in August.

Then, there will be future sessions to negotiate the content of both of those documents, and we certainly would want to follow your thoughts here about making certain that the binding document contains the protective measures that we would seek and that the nonbinding document plays a role in this, but does not undercut or deviate from the objective that you outlined, so that is how we see things unfolding. It will take several sessions to accomplish this. It will not happen in August.

Senator STEvens. Well, I welcome that statement, Mr. Chairman. I really hope that we proceed from the base that we have. I think we have achieved substantial protection in the Pacific of several stocks. I wish we had the same success as far as your area, New England. 
We almost had it, once. To Lloyd Cutler's great credit, he almost had the agreement up there, and it fell down because of the overall negotiations over the Beaufort Sea and Dixon Entrance. All three were tied together, and when one fell, they all fell. I think we should emphasize the protection for the agreements we have as we go into this new concept of a binding agreement for the areas where we do not have protection. Obviously, I would not like to sacrifice current protections of the Bering Sea in particular. That is my primary concern.

I do thank you all, though. I think you are doing a good job, and I am hopeful that we can find some way to deal with the issues about the Law of the Sea. I would like to be able to support the Law of the Sea Convention, but I have not decided yet whether I can from what I am hearing about the tribunals and how they could impact the existing agreements that we rely on so greatly in the Pacific area.

Thank you, Mr. Chairman.

Senator KERRY. Thank you very much, Senator Stevens.

Mr. Ambassador, the ICCAT continues to present some problems. Since Mexico is not a party and it continues to transship tuna, how will the FAO agreement address this? Where will we go?

Ambassador CoLson. Well, the reflagging agreement really does not touch on the trade issues at all. Of course, Mexico is going through a change, an election period now and a new government will be elected, but we have made substantial progress in getting the Mexican Government to give serious consideration to joining ICCA'T, and we are very close, I think, and if we can continue in the next administration the cooperation that we have had with them, I would expect them to join ICCAT very shortly, but since Will is going to be one of the new ICCAT commissioners, maybe he would like to say a word or two.

Mr. MARTIN. Well, I think that you have stated it very, very accurately, David. The document that we are referring to today is the U.N. Conference on Straddling Stocks and Highly Migratory Species. It may help us a bit there, too, Senator. It hopefully in the end will require that for a nation to participate in a fishery like the bluefin tuna, it must either join the ICCAT-in this case the regional fishery organization-or it must comply with its rules. So, this is going to be a focus that we will make not only within that U.N. conference negotiation, but also within ICCAT - to require all nations fishing for bluefin tuna to join ICCAT or comply with its conservation measures.

Senator KERRY. Let me just follow up. What is the status of our policy goal to end the commercial fishery for North Atlantic salmon?

Ambassador Colson. Atlantic salmon?

Senator KeRRY. Yes.

Ambassador COLSGN. Last year, we worked very closely with the National Fish and Wildlife Foundation to put together a deal that essentially bought out the Greenland fishery for a 2-year period. This was put together with both private money and some money we were able to pull together at the State Department to provide both a study forum for working with the Greenland Native groups-this is entirely a Greenland Native people's fishery in 
Greenland that takes U.S.-origin Atlantic salmon off the coast of Greenland, and we really need to work with them to find supplemental income alternatives for the amount of money that they make in that fishery.

We were able to get them to agree not to fish on Atlantic salmon for 1994 and 1995 with an option to renew that for the next 3 years. We will continue to see if we can put that together. Somebody told me today that there is a fairly substantial increase in returns to the Connecticut River this year, so maybe it is already paying off. There are a couple of these illegal fishing operations in the North Atlantic again that we are tracking that are targeting Atlantic salmon.

Since Canada has moved its Atlantic salmon fisheries off of the ocean, and they are fishing just in rivers, they are not intercepting any U.S.-origin fish, so the only directed fishery has been this small fishery in Greenland, and our objective is to find a way in working with them to basically keep them out of that fishery.

Senator KERRY. Through a buyout?

Ambassador COLSON. Buyout, some mechanism of that sort.

Senator KERRY. Gentlemen, I really want to express my appreciation to you. I have pushed you hard on this. I know Secretary Wirth shares a desire to move in this direction, and if you folks are underfunded or there are problems there, I really would like you to let us know, particularly on the enforcement side. I know Senator Stevens and I and others will try to address enforcement, because it does us no good to achieve these agreements and then simply let them be undercut by our lack of enforcement capacity.

Senator StEvens. May I have one last comment here, or question, really?

Senator Kerry. Absolutely.

Senator STEvens. I know you mentioned that the Sea of Okhotsk-we call it the Peanut Hole-and it has been held up here since last year; have you been able to find out what the objection is? I think it is because of NAFO provisions rather than the Peanut Hole area. What is holding us up? Have you all changed your mind about that bill, the overall bill, the Studds bill?

Ambassador CoLSON. Senator, the administration would be quite happy to see both the NAFO bill and the Peanut Hole bill passed. I think what happened is when you passed the Peanut Hole bill and sent it over to the House, they attached the NAFO bill to it and sent it back over here, and there were still some objections over here to the NAFO bill, so that you did not move on that package. And that is all up to you about how you link things and delink things here in the Congress. But the administration is supporting both of those bills.

Senator STEVENS. I do not have any dog in the fight over the NAFO bill, but I obviously have one in the other one. I would like to see them both move, but I do not know what is holding them up. Maybe I will have to talk to my friend here about that. But I would like to see that done.

That bill would prohibit U.S. fishermen from fishing the high seas area of the Sea of Okhotsk.

Ambassador Colson. Into the Peanut Hole, unless we are in a cooperative agreement with the Russians. 
Senator STEvens. And there has been no such entry yet, but it could happen at any time, and then you will face a different circumstance.

Ambassador Colson. Yes, sir. And it would really detract from a cooperative relationship that we have with the Russians on a lot of issues of great importance to us. It is a matter that in both the last two summit meetings, both President Clinton and, previously, President Bush, with President Yeltsin brought this up.

This is a very important issue for the Russians, and it is an area that we have a real potential for cooperating. We will be taking a delegation to Russia before the summic. And if we had something that we could work with there, this could even become a theme for the summit at the end of September.

Senator STEvens. Thank you very much, Mr. Chairman.

Senator KERRY. Thank you very much, Senator.

Thank you, gentlemen, very much. We will leave the record open if we have any additional questions to submit to you. I really appreciate your testimony this morning.

Thank you.

If I could ask the second panel to come forward right away.

Let me just say before you leave, Ambassador, that we are going to include the implementing language on the flagging agreement in the Magnuson bill. So, we will try to move that along as fast as we can. And I understand Senator Mitchell will have some questions on NAFO.

Thank you.

Ambassador Colson. Thank you.

Senator KERRY. Lisa, do you want to lead off?

Ms. SPEER. I would be happy to.

Senator KERRY. Thanks for coming in. If you all could summarize in 5 minutes or so, that would be helpful, and then we will put your full statements in the record. That will give us some time to ask questions.

\section{STATEMENT OF LISA SPEER, SENIOR POLICY ANALYST, NATURAL RESOURCES DEFENSE COUNCIL}

Ms. SPEER. Thank you, Mr. Chairman.

My name is Lisa Speer. I am senior policy analyst with the Natural Resources Defense Council.

Senator Kerry. Can you pull the microphone closer and speak up?

Ms. SpeEr. Sure.

My testimony today is on behalf of Greenpeace, the World Wildlife Fund, and the National Audubon Society.

Mr. Chairman, as you so eloquently summarized in your opening remarks, the world is facing a global fisheries crisis of unprecedented proportions. The UNFAO now reports that in one-third of the world's major marine fishing areas the catch has declined by 20 percent or more. And FAO warned in April that disastrous social and economic consequences await the entire industry unless better national and international fishing controls are imposed.

The United Nations conference is a major opportunity to begin to get control over what is happening to fisheries worldwide. Although the conference only deals with species that occur beyond 
the EEZ's of individual nations, it does have the potential to set important precedents for the management of fisheries internationally regardless of where they occur.

The need for an effective international regime is urgent, and the United States will have a very important role to play in the outcome of the United Nations conference.

Why should the United States care about this international conference?

The United States really has three principal interests in making sure that a strong international regime emerges from the United Nations process. The first is that this country has a major economic interest in the fisheries at stake here. For example, tunas comprise roughly one-quarter of the total volume of edible imported fish into this country each year. U.S. fishermen catch, as you know, hundreds of millions of dollars' worth of tuna, and most of that is caught outside of U.S. waters.

Other straddling and highly migratory species of importance to the United States include pollock in the Bering Sea, as others have noted, swordfish, as well as billfish. Recreational fishing on billfish annually brings in hundreds of millions of dollars per year.

The lack of an effective international regime has had a major impact on some of these species, and the potential for further damage to U.S. interest is very high. The three examples that obviously come to mind are the disastrous depletion of bluefin tuna, the problem in the Donut Hole that many have alluded to, and the severe depletion of swordfish in the North Atlantic, which has led to virtually the elimination of the recreational swordfish fishery there.

In addition, a number of species that are important to the United States are not managed by any international authority. These include North and South Pacific albacore fisheries, as well as swordfish and marlin in the Pacific. And these species are in desperate need of management.

According to NMFS, both North Pacific albacore and blue marlin are classified as overutilized. And no mechanism even exists to assess the status of most billfish in the Pacific, let alone effectively manage them.

Most commercially caught species of straddling and highly migratory fish are now fully fished or overexploited according to FAO. It is in the interest of the United States to get controls over these fisheries now before the increasing level of competition precipitates crisis, like those we have seen with bluefin, pollock, and swordfish.

The second reason that the United States has an interest in a strong international regime is its concern with the maintenance of marine biological diversity. This conference offers a major opportunity to move ahead and advance the conservation of related wildlife and the protection of that wildlife from the impacts that occur when fishing depletes them. And the interest of the United States in maintaining marine biological diversity could be served by a strong regime in that regard.

And last, I think the third principal reason the United States has an interest in this conference relates to the escalating conflicts that have occurred as dwindling supplies of fish have become the subject of increasingly intense conflict and controversy between nations over their allocation. 
So, these are a few of the reasons we think that it is clearly in the U.S. interest to pursue a strong legally binding regime. But to get there from here will require a substantial effort. The text that emerged from the March conference that other people have mentioned is in fact tepid, as you described, Mr. Chairman. Its conservation provisions are exceedingly weak, and the text is riddled with qualifiers that severely undercut its effectiveness.

In addition, it has no effective measures to deal with the fundamental problem here, which is overcapacity. It does require nations to deal with overcapacity, but it contains no specific requirements and no specificity in terms of how nations are to go about that.

There have been different ideas that have come up during this process for dealing with overcapacity. One of them was suggested by the Canadians early on in the process. It would eliminate the subsidization of domestic fleets that fish on the high seas once certain biological thresholds have been crossed. But, to date, those have received little support in the United Nations context.

A key question that remains is how much of this text or what succeeds it will become legally binding, and how much of it will be left to languish in some nonbinding declaration.

That, in our view, is a key question that will have to be resolved.

Strengthening the text will require vision and leadership on the part of the United States and a clear signal that the United States is serious about achieving a strong legally binding regime that will change the status quo and that will put the world's fisheries back on a sustainable track. We have begun to see this leadership emerge in recent weeks, but the United States will have to become much more aggressive if we are going to achieve a sustainable regime for these species.

Shifting quickly to flagging. As everyone knows here, reflagging is a serious obstacle to the conservation of and management of international fisheries. Vessels can simply reflag to avoid controls. And this has been a major problem in virtually every area of the international waters.

The agreement imposes important requirements on flag states to control their vessels. We strongly support this agreement. We think it is a credit to the State Department, under the able leadership of Ambassador Colson, and we think it ought to be affirmed by the Senate.

On driftnets, I would just note that Greenpeace has done an update of the report you referred to, Mr. Chairman, in 1994, in which it documents continued driftnetting by the Italian fleet. We strongly support, Senator Stevens, your point that the United States needs to become much more aggressive in enforcing the driftnet ban.

And I think that really raises the question about enforcing international agreements and how you do that. And one of the things that I know is in Mr. Benton's testimony-he calls for a reaffirmation of the driftnet ban, and that is an idea which we would strongly support in the context of the United Nations.

With respect to the Donut Hole agreement, we would just reiterate the support that others have voiced for that agreement. Again, it is a very strong agreement. I do not think anyone is inter- 
ested in doing anything at the United Nations that would detract from that agreement.

I think the United Nations process has the potential to enhance the U.S. position in the Donut Hole. And I think that will emerge over time.

With respect to the NAFO and Sea of Okhotsk issues, although I have very little expertise in either of those areas, I think the point has to be made that if the United States is going to have fishing vessels in a region that is covered by a regional management organization, it is incumbent upon us to join that organization. For us not to do so completely undermines the U.S. leadership and our ability to encourage other states to impose strict controls on their vessels, and ensure that their vessels comply with the management requirements that have been established in that region.

So, thank you very much, Mr. Chairman.

[The prepared statement of Ms. Speer follows:]

\section{Prepared Statement of Lisa Speer}

My name is Lisa Speer. I am senior policy analyst with the Natural Resources Defense Council, a national environmental organization dedicated to the protection of natural resources and public health. My testimony today is on behalf of the World Wildlife Fund, the National Audubon Society, and Greenpeace.

\section{THE UNITED NATIONS CONFERENCE ON STRADDLING FISH STOCKS AND HIGHLY} MIGRATORY FISH STOCKS

Under existing international law, individual nations have jurisdiction over fish within their 200-mile Exclusive Economic Zones (EEZs). However, fish do not respect political boundaries and many species occur both within the 200 mile limit and beyond it in international waters. These fish include highly migratory species like tuna, swordfish, marlin, and other billfish, as well as so-called straddling stocks that straddle the boundary between domestic and international waters. In addition, a few commercially important fish occur exclusively on the high seas.

Unfortunately, there are no effective international standards governing how nations must collectively and individually manage these species. As a result, management regimes for these fish have often failed to prevent overfishing, destructive fishing practices and drastic depletion. Some areas of the ocean with active fisheries for straddling and highly migratory populations lack any management regime at all.

Global fishing pressure on commercially valuable straddling and highly migratory species has escalated rapidly in the last decade to the point where most are fully fished or over-exploited, according to the United Nations Food and Agriculture Organization (FAO). The pressure on these fish mirrors a broader context of overfishing worldwide: thirteen of FAO's seventeen major global fishing regions are seriously depleted or declining, and the overall global marine catch has fallen by 4 million tons from its peak of 86.5 million tons in 1989. In April, FAO warned:

Unless industrial fishing fleets are controlled through national and international regulation, ${ }^{*} * *$ disastrous social and economic consequences await the entire industry, including food shortages in the coastal communities of developing countries where seafood provides the major source of dietary protein and minerals as well as jobs.1

Developed countries are not immune from the consequences of overfishing of these species. For example, excessive harvest of northern cod, a straddling population, both within the Canadian zone and outside it by foreign fleets contributed to the collapse and subsequent closure of the northern cod fishery within Canada's EEZ. Some 20,000 to 40,000 jobs were lost and entire coastal communities disrupted. The recovery of the fishery is not expected until well into the next century.

Increasing competition for these fish, rapidly advancing technology, and increasingly mobile fleets make the need for an effective international regime urgent.

1 FAO, 1994. News release dated April 13, 1994. 


\section{The U.S. Interest in Promoting a Strong International Regime}

\section{Straddling and highly migratory species are important to the U.S.}

Straddling and highly migratory fish species are of great significance to the U.S. For example, tunas make up more than one-quarter of the total volume of edible fish imported into this country each year. U.S. fishermen catch hundreds of millions of dollars worth of tuna annually, most of it outside of U.S. waters. Other straddling and highly migratory species of great significance to U.S. fishermen include swordfish, pollock in the Bering Sea, as well as marlins, sailfish and other billfish important to recreational fishermen. U.S. recreational fishing of billfish has been valued at hundreds of millions of dollars annually.

The lack of an effective international regime has had a major impact on some of these species and the potential for further damage to U.S. interests is high. For example:

- The international fisheries management organization charged with managing tuna and other highly migratory species in the Atlantic 2 has failed to prevent disastrous depletion of bluefin tuna in the western Atlantic, contributing to severe catch reductions for U.S. commercial fishermen.

- The lack of effective international controls has contributed to the severe depletion of swordfish in the North Atlantic and the virtual elimination of the U.S. recreational swordfish fishery there.

- Catches of pollock in the high seas "Donut Hole" area of the Bering Sea between the U.S. and Russia crashed from nearly 1.5 million metric tons in 1939,to less than 11,000 tons in 1992. A moratorium on fishing for pollock in the Donut Hole and on the associated populations in the U.S. and Russian zones has been in effect since the beginning of 1993, resulting in economic hardship for U.S. fishers and coastal communities. ${ }^{3}$

In addition, a number of species important to the U.S. are not managed by any international authority. These include the North and South Pacific albacore fisheries, swordfish and marlin in the Pacific, and sharks in both the Atlantic and the Pacific. Management regimes are clearly needed for these fisheries: both North Pacific albacore and blue marlin in the Pacific are classified by NMFS as overutilized; and according to NMFS no mechanism exists to even assess the status of most billfish in the Pacific, let alone effectively manage fishing for them.

Most commercially caught tuna populations are now fully exploited or overfished, as are many populations of billfish and most straddling stocks, according to the FAO. Because these fish are so important both in terms of imports into the U.S. and the domestic fishing industry, and billfish are so important in terms, of the recreational fishing industry, it is in the interests of the United States to see that an effective regime that ensures the sustainability of these species is established now, before the level of competition precipitates crises like those suffered by bluefin, swordfish and pollock.

\section{Ecological issues}

In May, a Workshop on Marine Biological Diversity convened by the National Research Council identified fishing as one of the principal current global threats to biodiversity in the oceans. The impact of global fishing of straddling and highly migratory species on marine mammals, birds, other marine life and the overall viability and resilience of marine ecosystems is of crucial concern. For example, there is concern that heavy pollock fishing has been a factor in the extensive population declines observed for Steller sea lions and seabirds in the Bering Sea. A strong international regime that includes protective measures for non-target species is crucial to better understanding and protecting marine wildlife from the direct and indirect impacts of fishing.

\section{Reducing conflicts between nations}

Competition and conflicts between nations have escalated as various fish populations have dwindled under unsustainable levels of fishing pressure. Some countries have made moves toward extending jurisdiction beyond their 200-mile EEZs to gain control over commercially important populations, raising concerns about open international conflict.

Accounts of skirmishes between competing harvesters of diminishing fish stocks are becoming more and more commonplace. For example, enforcement of a new $\mathrm{Ca}$ nadian law that provides for the seizure of foreign fishing boats, working outside

2 International Commission for the Conservation of Atlantic Tunas (ICCAT).

3 The recently concluded "Convention on the Conservation and Management of the Pollock Resources in the Central Bering Sea," signed last month in Washington, is designed to restore pollock in the Bering Sea and put the fishery on a more sustainable track. 
the country's 200-mile limit on the Nose and Tail of the Grand Banks threatens to exacerbate the already intense acrimony that has arisen in the wake of the demise of the region's groundfishery.

Similar fisheries conflicts are occurring with increasing regularity worldwide. Measures need to be taken to prevent these skirmishes from escalating into a series of fish wars. An international agreement that effectively addresses these conflicts is clearly in the interests of the United States.

\section{The UN Process}

Population crashes, the poor performance of a number of existing international management organizations and the increasing conflict between nations over fishing of straddling and highly migratory species led to an agreement at UNCED to conduct negotiations aimed at developing a more effective international regime for these fisheries. The UN negotiations began last year and will continue with a twoweek-session next month in New York. While this session was originally intended to be the last, we now understand that negotiations will likely continue after August with the goal of reaching agreement in the spring of 1995.

The agreement that emerges from this process has significant potential to improve the way fisheries are managed around the world and, to help ensure the integrity of ocean ecosystems. For this goal to be realized however, major obstacles to reaching a strong, legally binding agreement must be overcome and the negotiating text must be strengthened. ${ }^{4}$ The role of the U.S. in both efforts will be key. We have urged the United States to take the following initiatives:

1. Advocate the adoption of strong conservation measures: Strong minimum conservation standards are necessary to effectively address overfishing, depletion, and impacts on non-target species in their ecosystems. The U.S. took a leadership role in shaping and promoting the inclusion of precautionary management measures in the negotiating text during the March session. However, much work is needed to expand on and strengthen the language in the Chairman's negotiating text on precautionary measures, reference points and other key conservation issues. The U.S. will need to press hard to elevate the text.

2. Advocate the adoption of a legally binding global agreement that is comprehensive: A key issue in the upcoming negotiations will be to what extent the text will be legally binding. We strongly support a comprehensive legally binding text even if this means negotiations are prolonged for a year or two years. This is because in the absence of a legally binding regime, compliance with key provisions in the text on conservation, compliance, enforcement and dispute resolution will be voluntary. Without the force of law, we believe the text will have little impact on the status quo and the pressing problems of overfishing, depletion and international conflict that increasingly plague international fishing.

3. U.S. Leadership is Required: Unresolved conflicts between nations over key issues continue to stand in the path of reaching an agreement. Overcoming these hurdles will require vision and leadership on the part of the U.S. and a clear signal that the U.S. is serious about achieving a strong, legally binding global regime that will ensure the sustainability of the world's fisheries. A commitment to using the U.S.' considerable leverage to pressure other governments to come to an agreement will be essential.

\section{THE FLAGGING CONVENTION}

The "Agreement to Promote Compliance With International Conservation and Management Measures By Fishing Vessels on the High Seas," concluded last fall, represents an important step towards addressing the problem posed by vessels that undermine international fisheries conservation efforts. The Agreement focuses on one aspect of this problem, the flagging and reflagging of vessels to avoid fishing restrictions that would otherwise apply.

Reflagging is a significant obstacle to the effectiveness of international fisheries management organizations. Vessels dissatisfied with conservation measures imposed by its flag state can, simply reflag to a state that does not, impose such measures. The vessel is then free to fish as it pleases. The Agreement addresses this problem by imposing requirements on flag states to control the activities of their vessels and ensure that such vessels do not undermine the effectiveness of international conservation and management measures, among other things.

4 See attachment I for the comments of NRDC, the National Audubon Society, and the Center for Marine Conservation on the draf negotiating text that emerged from the most recent formal negotiating session, held in March. See attachment II for the recommendations of these groups and Greenpeace for U.S. actions prior to and during the August session. 
The effectiveness of the Flagging Agreement will depend upon the extent to which it is ratified. To further this goal, we urge the Senate to provide its advice and consent to its acceptance. In addition, we urge the U.S. to use its leadership to encourage other nations, particularly those that have historically issued "flags of convenience," to become parties to the agreement. Finally, we believe that the Agreement needs to be supplemented by other measures to prevent vessels from undermining international conservation measures that are under discussions at the U.N. Conference on Straddling Fish Stocks and Highly Migratory Fish Stocks.

\section{DRIFTNETS}

Despite the passage of U.N. Resolution 46/215, the fishing fleets of a few nations continue to use driftnets longer than 2.5 kilometers. Noncomplying nations need to be quickly identified, and appropriate enforcement actions imposed in accordance with the High Seas Driftnet Fisheries Enforcement Act (the Driftnet Enforcement Act). Specifically, the U.S. should expeditiously enter into consultations with nations whose vessels are in violation of Resolution 46/215. In cases where consultation does not successfully curb illegal fishing, the U.S. should deny port privileges and prohibit the import of fish and fish products as provided for under Section 101 of the Driftnet Enforcement Act.

Thank you.

Senator KERRY. Thank you very much, Ms. Speer. Mr. Benton.

STATEMENT OF DAVID BENTON, DIRECTOR, OFFICE OF EXTERNAL AND INTERNATIONAL FISHERIES, ALASKA DEPARTMENT OF FISH AND GAME

Mr. Benton. Thank you, Mr. Chairman. I will be very brief.

I think that the statements and questions that yourself and Senator Stevens asked the previous panel mirror the kinds of questions and concerns that we have from the State of Alaska.

Mr. Chairman, in the North Pacific, there has been significant progress made in the last 5 years. Five years or so ago, I can remember being in front of this committee facing a situation where we had 100 or so Japanese vessels fishing directly on our salmon in the North Pacific under the INPFC, a treaty the United States was a party to. We had 1,000 squid driftnet vessels from three countries fishing roughly 2 million miles of net a year in the North Pacific, and at least some of them were targeting on our salmon. These fisheries were also causing extreme impacts on marine mammals and sea birds and other fish.

And, at the same time, there was this unregulated Donut Hole fishery, conducted by four countries, that was taking 1.4 million metric tons or so of pollock in the Central Bering sea, thus exceeding the total pollock harvest inside our own zone.

Five years later, that Japanese directed salmon fishery on the high seas is gone. We have a new international agreement that prohibits taking salmon on the high seas. That agreement came about through close cooperation between the United States and Russia, and by taking a proposal that was put together between our two countries to Japan and Canada. And those four countries are now signatories to that agreement.

We have a new agreement on the Central Bering Sea, which we have all heard about here today, that is between six countries. This agreement controls the Donut Hole fishery and reinforces the role, responsibilities, and rights, of the coastal states to govern how a fishery might occur in the Donut Hole. And of course, we have the United Nations resolutions banning the use of high seas driftnets.

So, that, to us, is very significant progress. 
The problem that we have, Mr. Chairman, is that while we agree that the United Nations Conference on Straddling Stocks and Highly Migratory Species does present an opportunity, currently, we do not think that the text provides us any assurances that our interests are going to be protected. And, in fact, the result could undercut our position with regard to the straddling stocks in the Donut Hole.

As you have noted, the text is tepid. It is not designed to be a binding agreement presently. It pretty much, in my view, preserves the status quo, and it subjects the United States, if we were a party to it, to this mandatory dispute resolution process. And that could, indeed, jeopardize the agreements that we have reached in the Central Bering Sea, for example.

The results from this conference are coupled with the pending adoption of the United Nations Law of the Sea, and the United States becoming a party to that treaty, because, in many ways, the same kinds of mechanisms for dispute resolution are embodied in the Law of the Sea. And, we are also concerned that UNCLOS would be used to dismantle the nonbinding resolutions at the United Nations regarding driftnets.

If the United States is going to become a party to UNCLOS and become subject to binding dispute resolution mechanisms, then we are very, very concerned about the future of the driftnet moratorium over the long haul, and we really believe that the driftnet ban has to be reinforced through some kind of binding agreement.

And I think, Senator Stevens, that the questions you asked of Ambassador Colson and Will Martin from NOAA were right on the money. I think that they have not particularly considered the implications for driftnets or straddling stocks. They just want to get these things done and just move on. And I think that we need to encourage the administration to look at ways whereby we could reinforce the ban on driftnets and make that a binding part of international law, so that we do not have that problem in the future.

And I will close, Mr. Chairman.

Thank you.

[The prepared statement of Mr. Benton follows:]

\section{Prepared Statement of David Benton}

Thank you Mr. Chairman for this opportunity to testify before you today regard. ing international fisheries issues in the North Pacific. For the record, I am David Benton, the Director of the Office of External and International Fisheries, Alaska Department of Fish and Game.

I would like to speak today about a number of recent developments which we believe will have a significant impact on living marine resources in the North Pacific and Bering Sea, and the ability of the United States to effectively promote the conservation and management of those resources. The events 1 am referring to, Mr. Chairman, are the successful conclusion of a convention for the management of pollock resources in the Central Bering Sea, the implementation of the new North Pacific Anadromous Fish Convention, the recent change in the United States' position regarding the product of the U.N. Conference on Straddling Stocks and Highly Migratory Fish Stocks, and related matters.

Mr. Chairman, in order to fully appreciate the significance of these events, a little historical perspective may be in order.

In 1989, well over 100 Japanese salmon driftnet vessels were fishing on the high seas of the North Pacific and Bering Sea. This fleet was intercepting large numbers of North American salmon in a directed high seas salmon fishery authorized pursuant to the terms of the International North Pacific Fisheries Convention (INPFC). At the same time, nearly 1000 high seas driftnet vessels from Japan, the Republic 
of Korea, and Taiwan were fishing an estimated 30,000 miles of net per night in the North Pacific in the pursuit of squid, tuna, and salmon. These vessels were operating outside any international fisheries management regime, and were believed to be taking substantial numbers of North American salmon and steel head illegally, as well as having significant impacts on marine mammals, sea birds, sea turtles, numerous fish species, and other marine life. In addition, fleets of large trawlers from Japan, Korea, Poland, and the Peoples Republic of China were fishing in the Central Bering Sea donut hole, taking roughly 1.4 million metric tons of pollock in a free-for-all, unregulated fishery. This level of harvest exceeded the pollock harvest inside the U.S. zone, and led to the collapse of the Aleutian Basin pollock stock in 1991 just 2 years later.

In each of these instances, important U.S. fish stocks were at risk. In each instance, management regimes were either non-existent or, in the case of the INPFC fishery, so ineffective, that U.S. interests could not be protected. In both the driftnet and donut hole fisheries, enforcement was totally absent resulting in numerous major illegal fishing activities taking place.

Today, just 5 years later, the situation is somewhat different, Mr. Chairman. Enormous progress has been made over the past few years. Progress that has come about in large part due to leadership from this Committee.

Today, because of the leadership of the United States, there is a global ban on the use of large scale pelagic driftnets. The unacceptable impacts of driftnets on tuna and other fish stocks has ceased, the illegal interceptions of our salmon and stcelhead are gone, and the incidental takings of thou sands of marine mammals and hundreds of thousands of sea birds have ended, and the waste of millions of pounds of non-target fish has stopped.

The Japanese directed high seas salmon fishery, and the INPFC which authorized it, have been terminated. The INPFC has been replaced with the North Pacific Anadromous Fish Commission (NPAFC), which prohibits fishing for salmon and other anadromous fish outside the 200 mile zones of the North Pacific. The convenicn establishing the NPAFC has specific conservation and management measures for anadromous stocks and ecologically related species, specific obligations and duties for cooperation and coordination of scientific research, and strong enforcement provisions. The parties to the NPAFC are Russia, Japan, Canada, and the U.S. The Convention went into effect last year.

And, just this year, another new convention was completed. The "Convention on the Conservation and Management of the Pollock Resources in the Central Bering Sea" was initialed in February of this year in Washington D.C. by the United States, Russia, Japan, Poland, the Peoples Republic of China, and the Republic of Korea. This convention places a moratorium on fishing in the Central Bering Sea donut hole, and sets up a management regime to govern fishing once the stocks recover.

In just 5 short years, Mr. Chairman, the international fisheries management regime for the North Pacific has undergone a major restructuring. U.S. stocks are better protected. International cooperation on scientific research and enforcement has been expanded and improved. Cooperation among the major coastal states has been strengthened. How did these developments come about? They came about because of the ability and willingness of the United States to use trade policy, national and international law, and strong diplomacy around the world to persuade all of the parties concerned that these were serious matters that had to be resolved.

While these developments are certainly good news, other pending actions cause us to be concerned that the ability of the United States to address marine conservation issues in the future may be seriously compromised. There are three areas of particular concern:

\section{MANAGEMENT OF STRADDLING STOCKS}

The first issue has to do with the conservation and management of straddling stocks of fish. The United States has announced its intention to become a signatory to the U.N. Convention on the Law of the Sea (UNCLOS) in the near future. One of the major unresolved fisheries issues in UNCLOS is the conservation and man. agement of straddling stocks. The State of Alaska is intimately familiar with the straddling stock issue, given that we have been involved in one of the world's pioneer efforts to craft a straddling stocks convention to manage the Central Bering Sea donut hole fishery for Aleutian Basin pollock.

The U.N. Conference on Straddling Fish Stocks and Highly Migratory Fish Stocks is currently attempting to address the straddling stocks issue by setting broad international policies for governing the conservation and management of such stocks. 
The outcome of these negotiations could have significant ramifications on the successful implementation of the Central Bering Sea convention.

Up until recently, the position of the United States has been that the outcome of the conference would be a non-binding set of guiding principles. This was agreeable to U.S. given the general nature of the negotiating text and the principles which would be established. Now, the U.S. position has changed, and the U.S. has agreed to this document becoming a binding agreement. This causes us concern on three counts:

1. The text contains very general language which we believe will set an unacceptable "lowest-common-denominator" as the standard for regional agreements to address straddling stocks. This low standard could hamper efforts to develop strong requirements in future regional arrangements, and could impede successful implementation of the Central Bering Sea convention in the near term. Overalls the text dealing with straddling stocks needs to be more specific regarding the standards for regional agreements and the obligations of fishing states to conserve these stocks.

2. The text reaffirms the rights of coastal states, such as the United States, to manage straddling stocks inside their respective 200 mile zones, but does not strengthen the role of the coastal states in managing such stocks outside their zone. In the case of the Bering Sea, where the donut hole is less than 10 percent of the area and most of the spawning occurs in U.S. waters, we believe strongly that the U.S. has the primary interest in those stocks. If the United States is going to become party to this new agreement as well as UNCLOS, then this issue must be resolved in favor of the coastal states.

3 . The conference text, and presumable the new agreement, would subject the United States to compulsory binding international arbitration in order to settle disputes over the conservation and management of straddling stocks. Under the terms of the current text, such binding arbitration would apply to disputes in the Bering Sea, and could be brought about by nations which are not parties to the Central Bering Sea convention. This convention took roughly 5 years and ten rounds of negotiations to conclude. In the end we were able to negotiate an agreement between six nations which establishes internationally significant precedents for enforcement, and which contains very important conservation and management provisions which protect U.S. fish stocks and strengthens U.S. management of those stocks throughout their range. We question whether or not it is in the best interests of either the Aleutian Basin pollock stocks or the United States to then place this agreement and our interests under the authority of an unidentified international tribunal.

With the recent change in U.S. policy regarding the outcome of the UN conference, the State of Alaska believes that it is crucial that the U.S. thoroughly review the negotiating text, develop specific proposals to address these issues, and not accede to the agreement unless these issues are successfully resolved.

\section{IMPLEMENTATION OF NPAFC}

The second area of concern is the implementation of the North Pacific Anadromous Fish Convention (NPAFC). The NPAFC was intended to take the place of the old INPFC, which included not only matters pertaining to salmon, but other species as well. It was to be an important forum for international cooperation and coordination of scientific research and fisheries enforcement. This convention, and the commission it established, was clearly intended to be a centerpiece for international cooperation regarding high seas fisheries in the North Pacific.

By the terms of the convention, directed fishing for salmon and steelhead in the convention area is prohibited. Trafficking in salmon taken in violation of the treaty is prohibited. The incidental taking of salmon in a non-salmon fishery, e.g., the high seas squid fishery, must be reduced to the maximum extent practicable, and the burden of proof is on the fishing party to show that this requirement is being met. The retention of incidentally caught salmon is also prohibited.

The convention sets new standards for high seas enforcement. It gives Parties the right to board, inspect, seize and detain any vessel of any other Party which is found to be in violation of the terms of the treaty, or any such vessel for which there are reasonable grounds to believe is operating in violation of the treaty. Actual trial and punishment will be carried out by the flag state.

The convention also extends authority to the commission to address issues pertaining to the conservation of ecologically related species, which are broadly defined so as to include marine mammals, sea birds, and other species which are in association with salmon in the convention area. There are specific obligations for cooperation and coordination in scientific research, the collection and sharing of fisheries data, and other information necessary to attain the purposes of the convention. 
However, the provisions regarding ecologically related species and scientific research remain contentious, as Canada has sought to reduce the ability of the commission the address these issues. Canada is instead pushing for these issues to be placed under the authority of the North Pacific Marine Science Organization, commonly referred to as PICES. The difficulty here is that PICES is a broad-based scientific organization more attuned to large scale, multi-disciplinary ecological research than it is to the collection, storage, and processing of basic fisheries statistics or the management of high seas fisheries and their impacts on associated species.

This conflict is weakening the mission of both the NPAFC and PICES, and U.S. policy is unclear as to its resolution. The problem could be resolved by acceding to the Canadian demands, which would diminish the role of the NPAFC and substantially modify the role of the PICES organization. We would not advocate this approach. However, if this were the decision, we believe that the treaty establishing PICES would need to be renegotiated to include specific obligations for data collection and exchange similar to those in the NPAFC, and also to provide for PICES to engage in enforcement and management activities within the convention area.

The other approach is for the U.S. sections of both NPAFC and PICES to adopt consistent policies regarding these issues and the roles of the respective organizations. In this case, the U.S. position should be that the NPAFC should assume the role of primary responsibility for high seas management and enforcement for fisheries in the convention area, including a strong scientific research role covering a broad range of species in order to meet obligations for conservation and management in the convention area. PICES would assume the primary role for international cooperation in multi-disciplinary oceanographic and ecological research in the North Pacific. The two organizations would exchange data, and coordinate as needed on specific issues. If this is the path chosen, then it is imperative that U.S. policy be consistent and well coordinated.

\section{U.S. BECOMING SIGNATORY TO UNCLOS}

The third area of concern is the pending adoption of the UNCLOS by the United States and its impact on the ability of the U.S. to effectively achieve national goals to conserve living marine resources on the high seas. Like the text from the UN straddling stocks conference, UNCLOS requires parties to submit to binding international arbitration which in most instances will be conducted by an international tribunal. The decisions of such a tribunal are binding on all parties to the dispute, and are generally not subject to appeal.

If the United States becomes a full party to UNCLOS, then these provisions shall apply. This could have serious implications for not only future conservation issues which might arise and therefore be subject to such a procedure, but also for some of the significant gains which have been made in recent years on driftnets, straddling stocks, highly migratory stocks, and other species.

For example, the driftnet moratorium could be called before such a tribunal once UNCLOS comes into force. And it is likely, in our view, that the driftnet issue would be one of the first matters brought before such a tribunal. If the U.S. were a party to UNCLOS, then we would be bound by the decision of the tribunal. In the event that the tribunal reinstated the driftnet fishery, the U.S. would be in the unfortunate position of trying to renegotiate multiple international agreements to manage these fisheries even though we know from past experience that such agreements are largely ineffective, virtually impossible to enforce, and very expensive. Most importantly, our options for bringing pressure to bear on the fishing nations would be severely constrained, thus further ensuring the likelihood that any such agreements would be weak and not adequate to protect U.S. interests or the broad range of living marine resources which would be affected of these fisheries resume.

Similarly, the effectiveness of existing regional agreements would be called into question. States which are not party to the NPAFC or the Central Bering Sea convention could challenge these agreements, and potentially undermine their implementation. For example, a non-party could announce the intention to fish in the donut hole, and be rejected by the parties to the donut hole convention. This nonparty could then take the dispute to the international tribunal. If the tribunal rules against the parties to the convention, then there will be a new entrant in the donut hole fishery, which is something we have staunchly tried to prevent. If the tribunal rules that the management or allocation scheme provided for in the convention unfairly discriminated against this new entrant, then there would be even a further erosion of the agreement.

Mr. Chairman, these problems are not insurmountable. They are, however, very serious and deserve careful attention. If the U.S. secures specific language at the UN Conference on Straddling Fish Stocks and Highly Migratory Fish Stocks affirm- 
ing the primacy of coastal states with regard to straddling stocks throughout their range, then the problems for the Central Bering Sea convention are manageable. If the U.S. secures a reaffirmation of the driftnet ban in the straddling stocks/highly migratory stocks agreement, as well as in other international agreements including any documents concluded in relation to the ratification of UNCLOS, then the driftnet issue is manageable. However, if the United States does not secure such affirmations, then many of the gains we have made in the last 5 years or so will be severely undermined.

Mr. Chairman, thank you for your kind consideration in allowing me to present this testimony to you today. I will be glad to answer any questions you or the other members of the Committee may have.

Senator Kerry. Thank you very much, Mr. Benton. Mr. Burney.

\section{STATEMENT OF DAVID G. BURNEY, EXECUTIVE DIRECTOR, UNITED STATES TUNA FOUNDATION}

Mr. BURNEY. Thank you, Mr. Chairman.

As I pointed out in my written testimony, Mr. Chairman, I represent U.S. processors and all of the U.S. purse seine vessels that fish pursuant to the Western Pacific Tuna Treaty. We do not fish on bluefin tuna, I might add. And we do not fish in the Eastern Tropical Pacific.

There are two things that came up in your conversation with Ambassador Colson that are worth mentioning. One was the statement, a kind of an inadvertent statement by Ambassador Colson, that the United Nations conference should not infringe on existing fisheries policies.

I disagree with Ambassador Colson's statement, the United Nations conference should infringe on existing policies of nonmanagement and should infringe where there is no management of the fishery over the number of vessels that are allowed to participate in a fishery. This is the major objective of this conference.

I share the same concerns as Senator Stevens about dispute settlement. I also was privileged enough to be involved in the Law of the Sea negotiations. At that time I was representing the American Tuna Boat Association. We all recall how difficult those negotiations were. You had most of the countries in the world trying to decide what should be done with the common marine resources and the oceans of the world. It was not an easy task.

The present United Nations conference, which is directed toward the management of highly migratory fishery stocks and straddling fish stocks, still faces a monumental task. I am encouraged, however, that some resource management principles have been agreed to at the conference to date. The acceptance of a precautionary approach to fisheries management is a step in the right direction.

I am not saying that marks the end of the conference debate. The biggest issue facing this conference is the compatibility of effective management measures that will be applied on the high seas and that also must be applied inside the EEZ's of all of the relevant coastal states.

We lose sight every once in a while of the fact that over 90 percent of the world's fisheries harvest occurs inside of 200 miles, not on the high seas. We are always talking about trying to manage these resources on the high seas, while forgetting that each relevant coastal state dictates management strategies for the same resource when it is inside their zone. This may work in a country like 
the United States, which has taken the time and the effort to implement effective management measures that are compatible with other areas where the resource is found.

We deal with 16 island countries in the Western Pacific that participate in a tuna treaty with the United States. Of those 16 island nations, 12 of them are very small island nations. I sit on the investment development board of two of these small nations. I can assure you that every time someone agrees to pay you $x$ number of dollars to fish in the exclusive economic zone, there is a willingness to accept the money and allow the fishing. It is an economic necessity for some of these countries, regardless of how it affects the resource.

Therefore, the United Nations conference is extremely important. The conference must establish some framework for the effective management of these highly valuable and renewable fisheries resources of the world. We should not abandon the conference because it has such a difficult task ahead of it.

The substantive provisions of any conference agreement will answer the question for me, as to whether binding dispute settlement is acceptable or not.

If the substantive provisions do not protect those management agreements that we have already accomplished, obviously, there would be no reason to subject them to dispute settlement. On the other hand, if we are able to include in the substantive provisions of the conference agreement meaningful management measures that everyone around the world agrees to adopt, then it would be in our best interest to agree to dispute settlement.

The value of the conference cannot be judged at this time. We have got a long way to go. I would encourage the United States to stay involved and to take an active leadership role, especially if the objective is to produce a binding convention. If this is the objective of the conference, there are a lot of questions yet to be answered.

We are a distant-water fishing industry. The United States is unique in that it is both a distant-water fishing nation and a major coastal state. We, therefore, have a responsibility to the world community to take a leadership role at this conference. I am confident that if we do this, we can walk away with a final text we cannot only live with, but one which will go a long way to protecting the international fishery resources in the future.

Thank you.

[The prepared statement of Mr. Burney follows:]

\section{Prepared Statement of David G. Burney}

I appear here today on behalf of the U.S. Tuna Foundation, a non-profit trade association consisting of the major U.S. tuna processors and all of the U.S. purse seine vessels operating pursuant to the South Pacific Tuna Treaty.

We welcome this opportunity to address, what we believe to be one of the most serious challenges facing the international fisheries community. Simply put, the community must provide for the effective management and conservation of all international fisheries if we are going to sustain, in perpetuity, this highly nutritional and valued resource. In our opinion, this can only be accomplished through the close international cooperation of all Coastal Nations and all relevant distant water fishing nations (DWFN).

The U.S. tuna industry has long recognized the need for a coordinated and effective management regime for the highly migratory fisheries resources of the world. Tunas have been considered to be among the most valuable of these highly migratory fisheries resources. Therefore, we not only welcome the opportunity to testify 
here today, we share the concern and interest of this Committee in insuring that all highly migratory fisheries be effectively managed and conserved.

During my twenty years representing the interests of the U.S. tuna industry, 1 have served on numerous international tuna fisheries advisory committees and have been a member of many U.S. government delegations that have sought to achieve international cooperation in the licensing and managing of the world's tuna fisheries.

Presently, I am a member of the U.S. delegation to the UN Conference on Straddling Fish Stocks and Highly Migratory Fish Stocks. This Conference, which is attempting to fulfill the management mandate envisioned by the U.N. Conference on the Law of the Sea, will determine the future of most, if not all, of the international fisheries that fall into the two subject categories. At the very least, the Conference representatives intend to reach agreement on a set of scientifically recognized fisheries management principles that can be applied uniformly to the international fisheries for Straddling Fish Stocks and Highly Migratory Fish Stocks.

My background and experience in international tuna management and conservation regimes such as the Inter-American Tropical Tuna Commission (IATTC), the International Commission for the Conservation of Atlantic Tunas (ICCAT) and the South Pacific Commission (SPC) has given me a unique opportunity to observe both the successes and failures of international efforts to manage the highly migratory tuna resource. With the exception of the Atlantic Bluefin tuna stock, a stock not associated with our fishing vessels, these highly respected international tuna regimes have been extremely successful in monitoring the world's major tuna fisheries and have implemented effective management measures, when necessary.

I say this even though it is difficult to find any article or paper written today that, in commenting on the condition of international fisheries, doesn't express the view that all or almost all of the world's fisheries are threatened, endangered or on the verge of collapse. There is almost no good news reported when it comes to the state of international fisheries.

It is undoubtedly true that many of the world's fisheries are being overfished, some even to the point of nonsustainability. I am confident, however, that this is not the case with the world's major tuna fisheries.

The IATTC in the eastern tropical Pacific (ETP) and the SPC in the western Pacific Ocean (WPO) have a long history of collecting valuable data and monitoring the condition of their respective tuna fisheries. Each Commission has succeeded in maintaining its tuna fishery at a healthy and productive level. Bear in mind, these two major international tuna fisheries supply the world with approximately $2,000,000$ tons of tuna annually. Even so, the international scientific community is satisfied that each fishery is in a healthy condition and being fished within its maximum sustainable yield limits.

This doesn't mean that there isn't a need to improve and better coordinate the international cooperation that is necessary to preserve these highly valued fisheries. The UN Conference's major objective is to provide the necessary framework for the effective management and conservation of all international fisheries.

Nations participating in the UN Conference have developed a draft negotiating text that, if adopted by all relevant coastal nations and DWFN's, will become the blueprint for the effective management of these international fisheries. While there are a number of matters still to be resolved in the text, the basic premise, that international fisheries should be managed and conserved on \& "precautionary approach" basis is fully supported.

The precautionary approach to fisheries management recognizes the need to closely monitor each separate fishery, including the collection of vital data on both targeted and non-targeted stocks that are affected by the fishery. It also recognizes that any management measures that are adopted for the fishery must be based on recognized scientific principles of fisheries management, not just on a desire to regulate.

The precautionary approach to fisheries management that is set forth in the UN negotiating text acknowledges the importance, and also the limitation, on an ecosystem approach to fisheries management. The text provides that both targeted and nontargeted species should be monitored (data collected) but provides that non-tar-" geted species "should" be the subject of a management plan only, "as necessary." This sensible approach to an ecosystem based fisheries management policy is in contrast to the draconian measures proposed by some interested parties that seek the elimination of all by-catch within a specified time frame.

The scientific and technical panel of the UN Conference recognized that the elimination of all by-catch is technologically impossible in most commercial fisheries. They also recognized that some by-catch may be necessary in order to provide a continuing balance in the complex food-web system of the marine environment. Fur- 
thermore, the Panel agreed that the cost and possibility of developing an all encompassing management plan for the entire marine ecosystem was prohibitive and un. attainable.

Qne of the most difficult issues yet to be resolved at the Conference is the balance of rights and duties between coastal States and DWFN's. As this Committee is well aware, efforts to balance these competing interests was a contentious issue in the United States for years. Until recently, the United States did not claim jurisdiction over highly migratory tunas because it was acknowledged that tunas could not be effectively managed or conserved on a unilateral basis. As a result of this policy, the United States was instrumental in the creation and maintenance of the international tuna management regimes which were formed to monitor and maintain the major tuna fisheries of the world.

Although the United States now claims jurisdiction over the tunas that traverse its exclusive economic zone (EEZ), it still supports the scientific principle that effective management and conservation of tunas requires the international cooperation of all relevant Coastal Nations and DWFN's. The United States continues to support the need to manage this highly migratory fish species throughout its range. There can be no effective management if it is limited to the high seas or the EEZ's of relevant Coastal Nations.

Many Coastal Nations believe that any attempt to impose international management measures inside their EEZ's is an infringement on their sovereignty. They ignore the fact that in many cases, international treaties or multilateral arrangements do infringe on a nation's absolute sovereignty. In these cases, the infringement is normally weighed against the benefits to be derived from participating in such an international treaty or arrangement.

I have always viewed the sovereignty issue regarding tunas to be more economically based than conservationally based. It is a false premise to believe that a Coastal Nation actually owns the tuna that enter its EEZ. Tunas travel tens of thousands of miles luring their lifetime. They know no boundary or jurisdiction and move constantly from the high seas to the EEZ's of Coastal Nations and back to the high seas. Ownership cannot be traced over the life cycle of the migratory tuna.

Eifective unilateral management of highly migratory fish stocks, such as tuna, is not possible. Sovereignty over these fish stocks, if there is such a thing, merely means that when the resource enters the EEZ of a nation that nation controls who, how and at what price the resource can be taken there. The same fish can be taken by any nation once it exits an EEZ and appears on the high seas again.

It is both scientific fact and common sense that highly migratory tunas can only be effectively managed and conserved if the management measures are applied equally on the high seas and inside the EZZ's that are a part of the range of the resource. In other words, tunas must be managed and conserved throughout their entire range if the management regime is to be effective.

The South Pacific Tuna Treaty was repeatedly referred to at the UN Conference as an example of the type of international cooperation that is necessary to maintain an effective management regime for highly migratory fish stocks. While this Treaty involves only one DWFN (United States) and all of the Coastal Nations of a region, it is proof that effective management can be maintained in a region without unduly infringing on the claims of sovereignty over the resource being managed.

The Treaty provides for the monitoring and gathering of data from the entire range of the resource in order that proper regional management decisions can be made. Under the Treaty, management measures, which have been termed, "minimum terms and conditions" for operating in the area, apply throughout the range of the resource. While it has not been explicitly stated in the Treaty, there is an implicit understanding that the Coastal Nations and the DWFN (United States) must work cooperatively to insure that the agreed upon management measures are applied whenever the resource is found.

Since neither a DWFN or a Coastal Nation has an established international right to dictate management measures for highly migratory fish stocks found on the high seas, it is incumbent on both parties to reach a mutually agreeable set of management measures. This should not raise a sovereignty concern since each Coastal Nation must agree to a management measure before it becomes effective within the EEZ of that nation. In addition, the Coastal Nation maintains sovereignty over the highly migratory resource while it is in the EEZ, thus, assuring that the actual harvest of the resource there can only occur with the Coastal Nation's permission.

In summary, it is critical that the international fisheries community work cooperatively to establish effective management and conservation measures that will sustain in perpetuity the world's renewable fisheries resources. Unilateral efforts to protect or manage highly migratory fish stocks, such as tunas, will ultimately fail. Both Coastal Nations and DWFN's must recognize that a highly migratory fish 
stock can only be effectively managed if the management measures are applied equally and uniformly throughout the range of the resource. Efforts must be made to balance the sovereignty concerns with this scientific fact.

The United States, being both a Coastal Nation and a DWFN for tunas, is in a unique position to effect the outcome of this issue at the UN Conference. To date, the U.S. position has been steadfast that any agreed upon management principles or measures for highly migratory fish stocks must be applied uniformly throughout the range of the resource. We support the U.S. position and submit that there is really no viable alternative for the effective management of this valuable resource.

Senator KerRY. Thank you very much, Mr. Burney. Mr. Kaelin.

\section{STATEMENT OF JEFFREY H. KAELIN, EXECUTIVE DIRECTOR, MAINE SARDINE COUNCIL}

Mr. KAELIN. My name is Jeff Kaelin and I am executive director of the Maine Sardine Council. I am also here today representing the Associated Fisheries of Maine. I appreciate the opportunity to be here to provide you with our views about U.S. membership in NAFO, the Northwest Atlantic Fisheries Organization. Today's hearing has also given me the opportunity to consider our lack of support for joining NAFO against the related issues of U.S. implementation of the FAO Flagging Agreement and the ongoing U.N. Conference on Straddling and Highly Migratory Fish Stocks we have heard so much about this morning.

The lack of support for joining NAFO in our region comes from the realization that NAFO is not a straddling stocks regime. Fisheries resources under NAFO jurisdiction are not resources which are also under the jurisdiction of the New England Fisheries Management Council. NAFO membership, it is believe, could drain scarce fisheries research and enforcement resources from the Gulf of Maine and Georges Bank area.

While some of the fishing grounds within NAFO jurisdiction are U.S. historical fishing grounds, we do not believe that NAFO membership will ultimately lead to allowing Maine groundfish vessels to regain access to these areas. During the past several years, as this issue has been discussed time and time again, NAFO countries, under Canadian leadership, have not been able to offer even the smallest fishing quota in return for U.S. participation in the organization.

While a few Maine boats did fish in the NAFO area immediately after the World Court gave nearly one-third of Georges Bank to Canada in 1984 , taking no more than 4,000 or 5,000 metric tons of fish annually, these explorations produce limited amounts of marginal quality product and negative balance sheets. This fishery is not in these boats' business plans today. Instead, cooperative management efforts with Canada focusing on Atlantic herring, cod, and haddock-true straddling stocks of the U.S. and Canadian EEZ's-are ongoing today. We believe that these efforts should be built upon to ensure the development of sustainable cross-border fisheries in our region.

Turning to the flagging agreement and the straddling stocks convention, it is important for the committee to understand that our day-to-day fisheries management focus is not on FAO and U.N. negotiations, but on our coastal fisheries problems and opportunities, with significant time commitments dedicated to New England 
Council deliberations. These international negotiations are not transparent, in U.N. terms, for New England fisherman.

While the Associated Fisheries of Maine has not had the opportunity to consider the draft legislation to implement the flagging agreement which is before your committee, the Maine Sardine Council can certainly support its passage, but we do ask that you carefully review the bill to ensure that its enforcement provisions are no broader than those imposed on domestic fisherman operating without our own EEZ today. I just do not have the background to be able to make that determination myself.

We do believe that congressional approval of this important international agreement would allow the United States to remain a nonparticipant in NAFO without diminishing its international stature and support for the sustainable use of the living resources of the high seas around the world. Discussions with Ambassador Colson as recently as this morning, have led me to believe that the State Department can support this view.

While there has not been widespread review of the revised negotiating text of the U.N. Conference on Straddling Stocks by Maine fisherman, I would be surprised if the broad initiative would be opposed by anyone. As has been said by others this morning, it is a little bit weak and wishy-washy, as so many international agreements are. Relative to our relationship with Canada, of particular interest to us is the document's recognition of high seas allocations based upon historical fishing practices.

I believe that at this time I could predict widespread opposition to a legally binding treaty, because there has been essentially no industry and Fishery Management Council input into the process. The agreement is very poorly understood at this time. I am not an expert in this area. In preparing my remarks, I was thinking that the conference should certainly continue and make progress, but a treaty with the force of customary international law should be adequate to guide the high seas straddling stocks regimes that would be of interest to the United States.

We just are not plugged into the process, Mr. Chairman, and I think at this time we could not support a binding agreement. I guess the draft that we have looked at would not be a final treaty anyway. We do look forward to continuing to focus on this with you, and we do certainly recognize that there are some serious overfishing issues around the world. We are dedicated to trying to resolve those in our own backyard, and look forward to continuing working with you toward that goal.

That is the end of my remarks. I would be happy to answer any questions you might have.

[The prepared statement of Mr. Kaelin follows:]

\section{Prepared Statement of JefFrey H. Kaelin}

Thank you for the opportunity to speak with you about some Maine and New England perspectives on current issues in international fisheries conservation and management.

In addition to representing Maine's $\$ 40$ million canned herring industry today, my comments concerning the Northwest Atlantic Fisheries Organization (NAFO)are made in behalf of the Associated Fisheries of Maine (AFM). While my term as President of this organization ended earlier this year, I remain active in developing the AFM's government relations.policies. The AFM is a broad-based organization, rep- 
resenting harvesters and processors in several fisheries, which is dedicated to providing a forum for cooperative action.

I want to preface my remarks by stating that Maine's sardine industry has enjoyed a cooperative relationship with Canadian fishermen and fisheries managers for more than 100 years. In recent years, as has often been the case historically, as much as 50 per cent of the Atlantic herring which our processing plants utilize comes from Canadian waters. During 1993, 8000 metric tons were imported from Canada to supplement the 24,000 metric tons harvested from Maine, Massachusetts, and U.S. federal waters. Canadian sardine factories similarly utilize herring originating in U.S. waters. This cross-border trade occurs primarily during the winter months when herring landed in Gloucester, Massachusetts is trucked to Canadian plants.

As the development of a regional Atlantic herring management plan by the Atlantic States Marine Fisheries Commission and the New England Fisheries Management Council has progressed during the past three or four years, at least three informal bilateral meetings of fishermen, processors, scientists, and managers have occurred.

Since the time that the Senate ratified the "NAFO Convention" on July 23, 1983, industry support for U.S. participation in the organization has not developed. It has been difficult to articulate a U.S. fisheries interest in joining the organization primarily, I believe-because NAFO's jurisdiction does not reach straddling stocks of concern to New England fisheries businesses or managers. These stocks: Atlantic herring, and groundfish transiting the Hague Line on Georges Bank or in the Gulf of Maine, are managed as EEZ fisheries by the U.S. and Canada.

As I explained; informal and substantive Atlantic herring discussions are occurring. Within the past year, representatives of the National Marine Fisheries Service and the New England Fisheries Management Council have met with their Canadian counterparts to improve cooperation in fisheries management for transboundary cod and haddock.

While a handful of Maine boats explored a fishery within the NAFO's jurisdiction-on the tail of the Grand Banks-several years ago, these explorations produced limited amounts of marginal quality product and negative balance sheets. It has been three or four years since any of the AFM's member groundfish vessels have taken that trip. This fishery is not in these boats' business plans today.

This recent activation of a long-dormant traditional U.S. fishery began immediately after the World Court gave one third of Georges Bank to Canada in 1984, abruptly ending fishing opportunities for New England fishermen on many traditional fishing grounds. That decision had the effect of increasing the severity of New England's current groundfishery problems today by reducing the size of U.S. fishing grounds just as large offshore vessels-capitalized in part through U.S. government efforts-were being launched. it is interesting to note, particularly as we consider NAFO membership, that the straddling stock arguments made by the U.S. to the World Court prior to 1984 were rejected by the Court based upon an objective investigation of available fisheries data.

In August of 1987, I received the attached letter from Ambassador Edward Wolfe after he met industry representatives in Portland, Maine on July 29. In his letter, Ed wrote "*** We will not move towards accession to NAFO without assurance that there are benefits to the U.S. fishing industry **** (and) will also attempt to determine what incentives Canada may offer in exchange for membership in NAFO".

In April of 1993, Ambassador Colson met with AFM members and described the reasoning for President Clinton's administration to pursue NAFO membership, again, today. In short, I can say that our members still aren't convinced and don't believe that anything has changed. We do not recognize the NAFO regime as a straddling stocks regime. At the same time, our industry continues to support and work on cooperative management initiatives with Canada with a mutual understanding of the need to ensure the development of sustainable cross-border fisheries in our region.

We learned last week that the Administration has submitted draft legislation to implement the "FAO Flagging Agreement"-the High Seas Fisheries Licensing Act of 1994. In fact, it was just last week when the details of what is involved in the agreement became available to us. It is important for the Committee to understand that FAO and UN deliberations are not "transparent" for' fur industry. To the extent that we are aware that various international fisheries agreements are being discussed, our day-to-day. fisheries management focus jg on our coastal fisheries problems and opportunities.

Because we have been working in other areas, the AFM has not taken a position on this bill. The Maine Sardine Council does support its passage but we urge the 
Committee to carefully review sections 6 through 10 of the Act to ensure that its enforcement provisions are no broader than those imposed on domestic fishermen operating within the EEZ.

We believe that Congressional approval of this legislation would allow the United States to remain a non-participant in NAFO without diminishing its international stature in support of "the sustainable use of the living marine resources of the high seas".

In further considering the somewhat arcane but interesting ideas contained in the revised negotiating text of the UN Conference on Straddling Fish Stocks and Highly Migratory Fish Stocks, I can say that the Maine Sardine Council is also in support of these discussions and most of the Conference's goals. Again, the committee should recognize that the New England fishing industry has not been following these discussions closely. While the AFM has therefore not considered the text, I would be surprised if this broad initiative would be opposed by anyone.

Of particular interest would be the document's recognition of high seas allocations based upon historical fishing practices. The area of developed countries' obligations to developing states could be an area of concern in terms of the scarcity of fisheries research and enforcement resources in this country today.

I can predict widespread opposition, which I share, over these negotiations producing a legally binding treaty at this time, however. There has been essentially no industry and management council input into this process and the agreement is poorly understood. Its vague language in a number of areas would render it unenforceable.

The Conference should develop an agreement with the force of customary international law when it convenes again next month. These legal standards would be adequate to guide the development of straddling stock and highly migratory offshore regimes of interest to the United States.

Thank you for your attention to our views. I would be pleased to provide the Committee with any additional information and answer any questions which you may have for me.

LETTER FROM EDWARD E. WOLFE, DEPUTY ASSISTANT SECRETARY FOR OCEANS AND FISHERIES AFFAIRS, DEPARTMENT OF STATE

August 27, 1987.

Mr. JEFFREY KAELIN,

Maine Sardine Council,

Brewer, $M E \quad 04412$

DEAR JEFF: Thank you for your efforts in arranging and hosting the industry meeting on U.S. membership in the Northwest Atlantic Fisheries Organization (NAFO) for us in Portland on July 29. At Portland, as at all of the meetings, the message was clear. We will not move towards accession to NAFO without assurance that there are benefits to the U.S. fishing industry. The interchange of ideas at each of the meetings was productive and informative and we understand that there is no pressure at present for NAFO membership from the industry in New England.

The Ninth Annual Meeting of NAFO will take place in Halifax, Nova Scotia, September 14-18. 1987. My office and the Office of International Affairs in the National Marine Fisheries Service will each send an observer. They will report on the significant results of the meeting, if any, upon their return. We will keep you posted if there are important developments in this area. We will also attempt to determine what incentives Canada may offer in exchange for membership in NAFO.

Thank you again for your help and your advice.

Sincerely,

EDWARD E. WOLFE,

Deputy Assistant Secretary for Oceans and Fisheries Affairs.

Senator KeRRY. Thank you very much.

Senator Stevens has a scheduling conflict, so I am going to turn to him first.

Senator STEvENS. Thank you very much. I do have one. I am grateful to you for holding this hearing, Mr. Chairman, and I want you to know that Alaskans are proud of David Benton, what he has been doing in international negotiations, working with the State and NOAA in particular, to really provide more firm protection for our fisheries off Alaska. 
I only have one comment, and it might lead to a comment from Ms. Speer, but I think one of the great problems we have right now is to get the environmental groups and other groups who originally sponsored the marine mammal moratorium, and then made that a permanent prohibition against management of marine mammals, to realize that part of the depletion of the world's fishing stocks we are talking about is taking place because of the ever-increasing numbers of some marine mammals.

Our otters are all the way down to Mexico. People talk about the beluga whale as being endangered; it is far from being endangered. They look like whitecaps in the Cook inlet every year, there are so many of them we cannot believe it. They are a tourist attraction now because they come in such great numbers.

I do believe that we should protect the marine mammals that are endangered or threatened of being endangered, but we have an entire prohibition. We are not even allowed to come near them, to disturb them; that is a "taking" now under the new regulations, the marine mammal concept. And we all know what happened down in Seattle with that one sea lion that was threatening the Columbia River salmon.

I do think that what we need to do is to find some way to deal with enforceable concepts of management, not only applied to man, but applied to the predators of the sea. And I would be hopeful that we would find some way to start talking about the size of gear. We have, now, what is it, Dave, about 65 factory trawlers off our shore?

Mr. Benton. Yes.

Senator STEvens. I am told, Mr. Chairman, that if the number reaches 90 , there will be no need for any other means of harvesting fish in the Pacific as a whole. These are bottom-line fisheries. They operate year round, they do not operate in just one fishery as the tradition was in the past, they are operating in every fishery that is available and in every country that is available. And I think that before long we will have to classify them as being near to being as dangerous to the fisheries of the world as driftnets were.

And we have got to find some way to get a hold of the proliferation of fishing systems that really vacuum clean the oceans. And I think that some of those systems are natural. Some of them are marine mammals and some of them are man-made mammals that we need to regulate or find some way to deal with. Now, I do not know yet that we are going to get that kind of understanding. I wish, Mr. Chairman, we could have some in-depth review of the threats to the fisheries of the world, and see if we could not get the State Department and other people to start talking about limitations on gear as one of our main targets for the protection of our fisheries. here.

But, I am sorry, I do have to leave. I appreciate all of you being

Senator KERRY. Well, I associate myself with those comments. I think that we are certainly part of that ecosystem, and there nust be a balance and we are going to have to be very careful that we do not upset it completely, without any recourse.

Senator STEVENS. Thank you very much.

Senator KERRY. Thank you. 
Let me come back to implementation. There is a tension between a little of what you said, Mr. Burney, and what you said, Mr. Benton. For example, take the issue raised by Senator Stevens and others about the impact on Alaska of the United States subscribing to binding arbitration for international fisheries agreements. In your comments, Mr. Burney, you basically said there has to be some kind of international intrusion or we are not going to resolve these problems.

Do you see a way of balancing this need, Mr. Benton? If we are going to ask other nations to give something up and we are going to ask them to agree that there is going to be a limitation, then we also have to submit ourselves to some form of regulation? I suppose the key is not to rachet down, that there is only a racheting up to whatever the higher standard is, in the same way as we have struggled with NAFTA and other agreements. There has to be an acceptance that if somebody's local standard is a higher standard of protection, then that has to be upheld.

Let me let you deal with it.

Mr. BEnTon. Mr. Chairman, I agree with you, and let me use the Central Bering Sea Agreement as an example. Prior to the conclusion of that agreement, six countries were involved in the negotiations. Four countries were fishing. In about 3 or so years, the fishing nations depleted the stock out in the Central Bering Sea to virtual commercial extinction. It is just not profitable to go out there and fish for those fish anymore. The fish are just not there.

Prior to the conclusion of that agreement, the United States ceased fishing on that stock inside our zone, and we did that out of our concern for conserving that resource, and also to show the fishing countries "Look, if we are going to engage in these negotiations, this is a give-and-take set of negotiations. We will do our part." That concept is reflected in the agreement.

In the terms of the Central Bering Sea Agreement, no fishing, either inside or outside the zones, is to occur until the stocks reach a certain biological threshold. Above that threshold, fishing can commence, and there is a formula for determining an allocation of those fish to fishing operations inside the zone and fishing operations in the Donut Hole. So, the notion of compatibility that Mr. Burney was referring to, and that is reflected somewhat in this text, is, I think, embodied probably most clearly in the Central Bering Sea Agreement.

And I do not disagree with Mr. Burney's statements. Many of them are quite accurate, and our concern is that the text that we have seen at the U.N. is pretty much more of the same. It is as if someone rewrote the Law of the Sea but using slightly different language. It does not really get at the heart of the problem, which I think is what Mr. Burney was saying.

Senator KERRY. Do you want to comment, Mr. Burney?

Mr. BURNEY. Well, I appreciate those remarks.

Senator KerRY. You do not need to, but if you want to.

Mr. BuRNEY. Well, I just wanted to say one thing that I think is important. When we are trying to deal with this issue of compatibility, I guess we could either seek to reach the lowest common denominator or the highest. I would hope the United States would strive to reach the highest. And all I am saying is if it is good 
enough for inside a zone, or it is good enough on the high seas, then it should be good enough inside, and vice versa. If we do not do it that way, we are going to have a patchwork.

Senator KERRY. That may not be entirely true in that you may only be able to get a certain threshold in the international arena, but you may have, in the EEZ, achieved a higher one.

Mr. BURNEY. You could, and that is very true. I think what concerned me about the U.N. conference is all of its focus is on the high seas as if that is the answer, and that is not the answer. As I said, 90 percent of these fish stocks are taken inside.

Senator KERRY. Agreed. I understand that.

Well, Ms. Speer, do you want to comment?

Ms. SPEER. Yes. I wanted to respond to this concern that I think a number of people share about how this U.N. conference would impact our existing agreements, and I think that there is a tension between wanting to maintain maximum flexibility on the part of the United States and the need for a comprehensive international regime. And I would just say a couple of things.

First of all, if the rules that come out of this conference are good rules, then it will help us, not hurt us. And I think that the seeds for good rules are, in fact, in the text. For example, the text would do things like deny access to a fishery to any party, any nation that is not participating in or cooperating with the regional management organization that is in place.

For example in ICCAT, if a nation-if that provision makes it through this process, if a nation were not a party to ICCAT but fishing in the ICCAT region, they would then be prohibited from doing so, and the dispute resolution procedures would provide a vehicle for going against that nation and preventing it from undercutting the ICCAT measures.

I would also note, though, that the history of U.S. participation in regions has not been altogether stellar. We did not reach the Bering Sea Agreement until the entire pollock fishery was wiped out in the Bering Sea. ICCAT, even though we have been a member for a long period of time, is not a model of success in terms of the operation of a regional management organization. There are problems out there that the United States is facing now and will face more and more as the pressure on fisheries around the world increases, and I think it is in, ultimately, the U.S. interest to have a regime out there that covers the world and not take a region-byregion approach.

Senator KERRY. Mr. Kaelin, in your testimony you say that the Sardine Council supports the implementation of the FAO licensing agreement. Under that agreement, U.S. vessels that are fishing on the high seas would be subject to the requirements of regional agreements. Those regional agreements include NAFO. At the same time, you oppose the United States acceding to NAFO. So, there is a conflict in that, is there not? How can you continue to oppose being part of NAFO but then support FAO?

Mr. KaELIN. There would be a conflict-if I thought that Maine boats still wanted to fish in the NAFO zone, that would be a conflict. But as I said, they do not. I think that-

Senator KERRY. So, are you wiling to accede to NAFO? 
Mr. KaELIN. No. I think we are willing to accede to the FAO Flagging Agreement. Then you have control over vessels, you can keep boats out of the NAFO zone-and NAFO becomes even more irrelevant than it is today in that case. I just do not-we have not been able-no one has been able to convince the New England fishing industry or the New England Fishery Management Council that NAFO is relevant to our doing our job of managing our coastal fisheries better.

I think it was wrong, perhaps, for a few vessels to fish on the tail of the bank in the NAFO zone a few years ago when we lost that portion of Georges to the World Court decision. It was a relief valve kind of a situation. There was not pressure by the administration at the time to join NAFO. We had not made progress in some of the international agreements that you have been discussing this morning; the Donut Hole Agreement was still in a formative stage. In fact, I was fortunate to participate in negotiations in the Soviet Union on that agreement to help Alaska interests move forward there.

But the point is that if we were still fishing in the NAFO zone, I think it would be very difficult for us to come down here and say do not accede to NAFO, but we are not doing that.

Senator KERRY. Well let me ask you this; I understand Maine fisherman do not want to fish there now and there are no plans to fish there in the near future and so forth, but we cannot receive a quota-the country cannot receive a quota under NAFO unless we are parties to it. And so why would you forgo the future possibility of getting a quota?

Mr. KAELIN. Well we think, given the situation, the fisheries situation in the Canadian EEZ and offshore there, that the likelihood of receiving any substantial quota is very small. We would like to continue to pursue the opportunity to regain access to some historical fishing grounds off Canada, but we do not think these efforts should be linked to NAFO membership.

Senator KERRY. What would the drawback be to New England fishermen if the United States were to accede to NAFO?

Mr. KAELIN. We think that it would drain National Marine Fisheries Service resources out of the region, focusing on stocks that are not of concern to the fishing industry up there. The enforcement issues - the enforcement costs would become an issue, I think, only if there were 14 or 15 boats in the zone, according to the convention. Perhaps enforcement costs are not an issue.

I guess we just see it as totally irrelevant to what we do on a daily basis in terms of managing the fisheries that we feel we have a responsibility to manage. We think that the flagging convention actually gives the United States the ability in the international community to say we are controlling access to the NAFO zone, that it is irrelevant to our industry and to our management focus here in New England, and have a good time up there.

I think-I believe, personally, that one of the biggest reasons why Canada wants the United States to be a member of NAFO is to help put pressure on the EC to do the right thing in the zone. And, frankly, the EC is not a big friend of ours in New England. We cannot sell our Maine sardines in EC countries without relabeling them; we have not made any progress in the GATT on 
that issue. The old fish-and-chips policy that was around on JV's and so forth, did not produce the shoreside commitments that the Dutch and some of the other EC nations promised at that time. And so I think that adds to why we believe that the whole issue is really an irrelevant one to us from a fisheries management prespective.

I will not go any further than that. I think we came here todaywe welcome the opportunity to make it clear to you where we were coming from on this issue because, as I indicated in my testimony, this is not new. We have been talking with the State Department since 1987, consistently, on whether or not we should join NAFO. And, again, I think if we accede to the straddling-to the flagging convention-

Senator KerRy. Well, does it make it hard for the United States to press for these other agreements if we are unwilling to be part of another regional agreement?

Mr. KAELIN. I do not believe so, because I think we argue, then, that we are a party to international agreements where we have an interest, and I do not believe that there has been-

Senator KERRY. Well, why should not any other nation, then, say to us, we are not going to be a party to any of these agreements because you are not willing to be a party to that, and you seek a double standard. I mean, do you want us to give up our fishing-

Mr. KAELIN. No, I think the key-and you certainly have a lot more background in international affairs than I do, but I think the key is whether or not those nations have an interest in being part of that organization.

Senator KERRY. Well, we all understand that no nation has an interest in giving up its fishing rights unless every other nation is also going to live by the same standard.

Mr. KaELIN. Well, to me the key is whether in is a domestic interest in the organization. I do not see $\mathrm{NAF}^{\prime}$ membership, in terms of fisheries management, as making proq ess in managing the resources that are important to us in New Englaind. And, focusing on the straddling stocks of concern to us in the Northeast, which are not within the NAFO jurisdiction, I think we say to those countries around the world, we are not in NAFO because we do not have a U.S. fisheries interest in NAFO. In fact, we have acceded to the flagging agreement, and our boats are not able to fish there, period. I think that is a resolution of the issue, in my mind.

Senator KERRY. Ms. Speer, how would you characterize the discussions at the U.N. at this point with respect to overcapitalization?

Ms. Speer. Minimal to nonexistent. There is a paragraph in the draft agreement that is exceedingly weak. It requires states to take measures to deal with overharvest and overcapacity and to ensure a level of fishing effort commensurate with the sustainable utilization of fisheries resources. Ali of us could agree with that statement. The problem is that there are no specifics to it. And it is the specifics that are going to be where the leadership is going to be required.

Senator KerRy. What is the environiriental community suggesting ought to be done? 
Ms. SPEer. Well, I think there are a number of ideas out there for limiting capacity. One of them is to establish thresholds in individual fisheries so that once a threshold is passed, which indicates either maximum utilization or overutilization, you have an automatic cut or closure of the fishery.

Mechanisms that are established, preagreed mechanisms that are established to trigger preagreed actions to cut the level of pressure on a fishery, could be incorporated into this and in fact have been discussed in the context of the U.N. negotiations, and I think there is some promise there but I think it is going to take a lot of work and I think it is going to really need-this issue and the need for conservation, the need for protection of other species besides the target species, needs to be elevated. There needs to be more attention paid to these issues. We need to hear more about this from leaders of nations, including the United States.

Senator KERRY. I agree with you completely. It is extraordinarily important to raise this to the summit level, if you will, and put pressure on these nations to begin to deal with it. Otherwise, we are just going to, I think, continue down this road of incrementalism which is disaster in itself.

ivir. Burney talked about tuna management compared to other fisheries, and pointed to the success there, but obviously, we still are concerned about the successful implementation of the ICCAT. How would you compare the ICCAT structure and its effectiveness with the other two agreements that you are involved with, the tropical tuna convention and the South Pacific convention?

Mr. BURNEY. Well, Mr. Chairman, I think that the key to any of these international organizations, for them to be effective they have to have good data. Without the data then it is guesswork and it becomes the political will of each of the parties to that particular convention. In the Inter- American Tropical Tuna Commission they have an independent scientific organization that monitors the status of the stocks. The South Pacific Commission does that out in the Western Pacific. Those scientific bodies are not fettered with all of the political arguments that go on at ICCAT.

ICCAT has been very political, and as the science evolves in ICCAT it is always debated on what is good science and what is not good science. Because of the independent scientific body of the South Pacific and the IATTC, they bring the science to the political table, and therefore it is the only science that anybody relies on. It is not that each country brings their own science and then argues that their science is the correct science.

Senator KERRY. Do you think that is why the South Pacific treaties have worked versus the ICCAT, or is there some other distinction?

Mr. BURney. I think in terms of the South Pacific Tuna Treaty it relies on the South Pacific Commission which is separate and apart from the treaty partners for the purposes of determining the status of those stocks, and every year that we have an annual meeting the South Pacific Commission brings a report to that group on the status.

Senator KERRY. Do you think they would make a generally accepted scientifically based decision?

Mr. BurneY. Absolutely. 
Senator KERRY. And ICCAT does not?

Mr. BURNEY. I believe that ICCAT is extremely political as it deals with the bluefin tuna issue. That is a very difficult issue because there is a limited amount of resource and a lot of people that want it, and as a result I believe ICCAT has been more involved with allocation than science for a number of years, and when science does creep in there are differing views on the science. It is not just one scientific body saying this is what the science is. I think that makes it very difficult.

Senator KERRY. Have you seen the implementing language on the FAO agreement?

Mr. BuRNEY. Yes.

Senator KerRY. Do you agree with it?

Mr. BuRnEY. Yes.

Senator KERRY. Do you support it?

Mr. BURNEY. Yes.

Senator KeRRY. Mr. Benton, in your testimony you raised the question of potential conflict between the need for strong ecosystem management to ensure that straddling stocks such as Bering Sea pollock are protected, and the need to clarify the rights of coastal states to manage stocks primarily within their 200 -mile zone. This goes back partly to my first question. How do you resolve the tension that exists there?

Mr. BENTON. Well, Mr. Chairman, the tension really comes about from the experience we had again with the Central Bering Sea. We had a situation where we could get the countries participating in those negotiations to come to the table. That was not a problem. And we could get them to discuss what we ought to do. That was not a problem.

Getting an agreement on what to do about the problem took 3 or so years and 10 sets of negotiations. What I was trying to capture was that, if we are going to become a party this new straddling stocks agreement, then the agreement needs, at least with regard to straddling stocks, to give us a little bit better handle on how we can exercise our rights regarding those straddling stocks.

In the case of the Bering Sea, 60 to 80 percent of the spawning is inside our zone. The Donut Hole is 10 percent of the area of the Bering Sea; the rest is in either our zone or the Russian zone. It seems to us that we have a primary interest in those straddling stocks. We do not necessarily believe that you have to come out of the U.N. conference with a declaration that coastal states have a sovereign interest of some sort over those straddling stocks, but it should be some kind of strengthening of the role of coastal states with regard to straddling stocks.

It is very different in highly migratory species. One of the problems with this text and the approach that has been used at the negotiations is that you are dealing with two distinct kinds of situations, straddling stocks and highly migratory species, with much of the same kind of language. Arid frankly, if we had our druthers we would have that distinction more accurately and precisely drawn so that measures that were particular to straddling stocks would be focused on straddling stosks. That would allow you to have more precise, and I think more meanıngful, language in the agreement, 
and similarly you would focus in on the peculiarities of highly migratory species and what you need to do to manage them.

That is not intended to negate the idea of compatibility between inside and outside the zones and measures that are applied. I think that those measures need to be fair, they need to be applied throughout the range of the stocks. That is not a question in our mind.

Senator KeRry. Let me ask both you and Mr. Burney if you would quickly comment on the same question I asked Ms. Speer regarding overcapitalization.

Mr. BURNEY. That is a very difficult issue. I look at what the real world offers, and in tuna today no one is building a new tuna vessel. Today, to build a purse seine vessel is $\$ 15$ to $\$ 18$ million, at a minimum. It is very difficult for anybody to rationalize that investment in this business today.

However, there always appears to be additional vessels that come out of mothballs whenever the price reaches a certain level. That is just the history of this business. And I think Ambassador Colson said it well, that we are dealing with a lot of countries today that have entered this business that were not in the business even 5 years ago, 3 years ago.

Overcapitalization is always an issue. It is something that I think has to be addressed and cannot just be ignored, and at the same time it has to be a rational approach to overcapitalization. That is the difficulty. As Mr. Benton just said, just as there is a difference between a straddling stock and a highly migratory fish stock there is also a difference between fisheries. In some fisheries, overcapitalization is a very serious problem. In others, the cost of entry is so high that overcapitalization has not been that big of a factor. And I think that is true with tuna, to a certain extent.

Senator KERRY. I appreciate all of your observations this morning. I think that I will also leave the record open with respect to this panel so that we could submit either written or additional questions.

I appreciate your comments of support for the views I expressed at the outset regarding the inadequacy of the current approach. None of these comments, yours or mine, are guaranteed to produce a solution automatically, but we clearly need to ratchet up the stakes here, and I am going to do everything I can. Senator Stevens and I have agreed to insert something into the defense bill with respect to NATO obligations and fisheries enforcement. In addition, we have agreed to draft a letter to both the Secretary of State as well as Italian authorities with respect to driftnet violations and try to heighten awareness on that.

But I think we need to be much more intense about international fish conservation and focus on it with a greater sense of urgency. I look forward to working with you, particularly with the groups here in Washington, to think about how we are going to do that. We simply cannot continue down the same road. Obviously, the price of fish is going to go up in the future because of increased scarcity, which means it will be more economical for more of those boats to try and catch this depleted prize. Then you all know what is going to happen. Obviously, with that intensity of effort we are going to diminish fishery resources even further. 
On a grander scale, what we are seeing with fisheries globally is the same thing we have been through regionally, and we know what we are doing there now. We are reducing effort, reducing days at sea, reducing catch, and we will have no alternative but to do the same globally. The question is whether we pursue management in an orderly fashion or whether it is going to be every country and fisherman for themselves with fish warfare on the seas and huge international tensions resulting.

There will be enough tension if we simply try to manage in an organized way, but I think we are better off trying to do that. I am going to urge Secretary Wirth and others to heighten the level of attention to these issues, and we will see where we go.

Thank you for being part of this today. We appreciate it.

We stand adjourned.

[Whereupon, at 12:42 p.m., the hearing was adjourned.] 



\section{APPENDIX}

\section{Prepared Statement of National Resources Defense Council, National Audubon SOCiety, aNd CENTER For Marine Conservation}

\section{INTRODUCTION}

The next few months will be crucial in determining whether the UN Conference on Straddling and Highly Migratory Fish Stocks will succeed or fail in developing a sustainable regime for international fisheries. Strong leadership from the United States is required if success is to be achieved. A key intersessional meeting of the principal parties this month in Buenos Aires presents a major opportunity to lay the groundwork for agreement. We urge the US to take the lead in pressing for strong, legally binding measures for conservation and management of international fisheries at the intersessional meeting and in the August session of the UN Conference. In the absence of such leadership on tee part of the U.S., we believe the Conference is doomed to failure.

The need for a sustainable international regime is increasingly urgent. Most commercially caught fish species that occur in international waters are already fully fished or depleted and demand continues to rise. In April, FAO warned of "disastrous social and economic consequences," including food shortages in coastal communities of developing countries, unless industrial fishing fleets are controlled through national and international regulation. ${ }^{1}$ In the absence of effective international controls, continued overfishing and depletion will endanger an important source of food for the world, threaten jobs in the commercial and recreational fishing industries, disrupt the social and cultural fabric of fishing communities and threaten marine mammals, birds and the overall viability and resilience of marine ecosystems.

\section{BACKGROUND}

Under existing international law, individual nations have jurisdiction over fish within their 200-mile Exclusive Economic Zones (EEZs). However, many commercially important fish populations, including most tuna species, migrate over vast areas of the ocean, often crossing the EEZs of several nations as well as the high seas. Other species, known as "straddling stocks," straddle the 200 mile boundary between international waters and national zones of jurisdiction. Effective management of both types of species requires cooperation between all nations with active fisheries on them.

Unfortunately, there are no effective international standards governing how nations must collectively manage species that occur both on the high seas and within the EEZs of one or more nations. As a result, multi-national regional organizations established to manage fishing of such species have often failed to prevent overfishing, destructive fishing practices and drastic depletion. Some areas of the ocean with active fisheries for such species lack any management regime at all.

Global fishing pressure on these species has increased rapidly in the last decade to the point where most are fully fished or overexploited according to the United Nations Food and Agriculture Organization (FAO). Some, like bluefin tuna, are in a state of crisis and others may soon follow. Increasing competition for tuna and other species that occur both on the high seas and within EEZs, together with rapidly advancing technology and increasingly mobile fleets, make the need for an effective international regime pressing. ${ }^{2}$

1FAO, 1994. "Major Fish Stocks Drop as Hi-Tech Subsidized Fishing Fleets Mine Oceans, FAO Reports: Urges Prucautionary Fisheries Management and Increased Controls Over Ocean Fishing." News Release dated April 13, 1994.

2 For a more detailed discussion of the increasing depletion of fish that occur in international waters, see "Toward Sustainable Fisheries," an NGO white paper prepared by U.S. environmental groups in January, 1994. 
Stock crashes, the poor performance of a number of existing regional management organizations and the increasing conflict between nations over fishing of species that occur both within and beyond the EEZs of individual nations led to an agreement at UNCED to conduct negotiations aimed at developing a more effective international regime for these fisheries. The UN negotiations began in July of 1993 and one more formal negotiating session is scheduled for August of this year. The most recent session of the Conference took place in March. At the end of the March session, the Chairman produced a draft negotiating text that will be the basis of further talks.

\section{THE DRAFT NEGOTIATING TEXT}

The Chairman's negotiating text has the potential to dramatically improve the conservation and management of international fisheries. For this goal to be realized however, major obstacles to reaching a strong, legally binding agreement must be overcome and the negotiating text must be strengthened. The role of the U.S. in both efforts will be key. Between now and the August session, we urge the US to undertake the following initiatives.

\section{A. Advocate the adoption of a legally binding global agreement}

A key unresolved issue that will be discussed at the intersessional and in August is whether the text as a whole will be legally binding.

We believe that the text must be legally binding, even if this means negotiations are prolonged for a year or possibly two years. This is because in the absence of a legally binding regime, compliance with key provisions in the text on conservation, compliance, enforcement and dispute resolution will be voluntary. It is clear from the disputes that have raged over straddling and highly migratory species that voluntary solutions will not solve the problem. Nations need a way to enforce the agreement if it is to be effective. ${ }^{3}$

We do not wish to minimize the difficulty of achieving a treaty on these and other issues. But without the force of law, we believe the text will have little impact on the status quo and the pressing problems of overfishing, depletion and international conflict that increasingly plague international fishing.

\section{B. Advocate Strengthening the Conservation Provisions of the Negotiating Test}

The U.S. took a strong leadership role in shaping and promoting the inclusion of precautionary management measures in the negotiating text during the March session. However, much work is needed to strengthen the language in the Chairman's negotiating text on precautionary measures, reference points and other key issues. Attachment 1 outlines some of the revisions to the text we believe are necessary to achieve a strong, pro-conservation international regime. We urge the U.S. to vigorously pursue these changes.

\section{U.S. Leadership is Required}

Unresolved conflicts between nations over compatibility and other key issues continue to stand in the path of reaching an agreement. Overcoming these hurdles will require vision and leadership on the part of the Clinton Administration and a clear signal that the U.S. is serious about achieving a strong, legally binding global regime that will ensure the sustainability of the world's fisheries. A commitment to using the U.S.'s considerable leverage to pressure other governments to come to an agreement will be essential. Neutrality on the issue of a legally binding regime must be replaced by vigorous advocacy in favor of it.

\section{ATTACHMENT 1-RECOMMENDATIONS FOR IMPROVING THE CHAIRMAN'S DRAFT NEGOTIATING TEXT}

\section{A. Precautionary management}

The draft text requires that the precautionary approach be applied widely to fisheries management both on the high seas and within EEZs in order to protect the marine environment. This represents an important recognition of the need to manage fisheries in a precautionary manner and to do so throughout their. range, re-

3 The UN resolution banning the use of large scale driftnets is sometimes cited as an example of a non-binding UN resolution that has been largely effective. However, it is widely acknowledged that one of the main reasons that it has been effective is because it was a single-issue resolution that was backed up by the threat of US trade sanctions to enforce the resolution. (The US has the largest tuna market in the world.) A UN declaration consisting of numerous principles and guidelines governing straddling stocks and highly migratory species is unlikely to be backed up by similar sanctions, and thus is unlikely to be similarly effective. 
gardless of political jurisdiction. However, a number of the provisions specifying how the precautionary approach is to be applied are extremely weak and in some cases would establish a very bad precedent. It is of crucial importance that this section be strengthened in the following manner.

\section{Management Reference points (or thresholds)}

States and regional organizations should be required to set management reference points (or thresholds) that trigger predetermined courses of action (such as closure of a fishery) for every species fished as well as for key associated and dependent species. Although the text contains good language requiring that measures be taken to avoid exceeding reference points for target species and that pre-agreed recovery plans be implemented if such reference points are exceeded, it does not require states to establish reference points in the first place for either target or non-target species. This is a major failing that must be corrected.

The guidelines in Annex 2 specifying how thresholds are to be developed are toothless and represent a significant departure from the stronger guidelines prepared by the working group on reference points convened by the Chairman during the March session. Even the original guidelines prepared by that group, if made mandatory, provide only a starting point for specific measures that are needed to give this section effect.

\section{Uncertainty}

Uncertainty plagues all aspects of fisheries management, and the text requires states to take into account uncertainty when managing fisheries. However, the precautionary section of the text contains an inappropriate reference to socio-economic conditions. Such conditions are not relevant to scientific uncertainty and the need for precaution, and reference to them in this section should be removed.

In addition, the March working group on reference points drafted specific recommendations on incorporating uncertainty into management. This type of specificity is critical to give this important section the content it needs to be effective.

\section{Non-target species and ecosystem management}

The text requires that states "should consider" associated ecosystems; develop data collection and research programs to assess the impact of fishing on non-target species and their environment; adopt plans "as necessary" to ensure the conservation of non-target species; and "consider" the protection of habitats of concern. These are all very important elements of a precautionary approach to fisheries and must be made mandatory if they are to have an impact. Qualifiers like "as necessary" undermine effectiveness and should be removed.

\section{New or exploratory fisheries}

We are concerned about language in this section requiring cooperation with those initiating a fishery in setting management measures. Such measures should be based on the biological characteristics and conservation needs of the population concerned, without undue interference by the person(s) initiating the fishery. In addition, conservation measures should be in place prior to the initiation of a new or exploratory fishery.

\section{B. General Principles}

The text contains a section enumerating general principles by which straddling and highly migratory fish stocks are to be managed on the high seas. We believe these principles, amended as suggested below, should apply to straddling and highly migratory fish stocks throughout their range, both on the high seas and within EEZs.

\section{MSY and optimum yield}

The text repeats language in UNCLOS Article 119, setting out "maximum sustainable yield as qualified by relevant environmental and economic factors" as a goal. Similarly, the text requires states to "adopt conservation and management measures to promote optimum utilization and ensure long-term sustainability of fish stock(s) as concerned. ***"

The terms "maximum sustainable yield" and "optimum utilization," as used in the text and in UNCLOS, are outmoded and probably contradictory with the goal of sustainability. (The problems with maximum sustainable yield as a management goal were discussed at length in the management reference points working group and in FAO's paper on management reference points). In the spirit of moving beyond UNCLOS, the text provides an important opportunity to redefine maximum sustainable yield and optimum utilization in a manner that ensures sustainability. 
In addition, the use of the words "long term" with sustainability may undercut the concept by allowing an inference that unsustainable fishing is permissible for a short period. Instead, states should be required to adopt measures that ensure continuous long term sustainability.

Finally, states should be required to adopt conservation measures to ensure the sustainability of not only the target species but also species dependent on or associated with target species.

\section{Overcapacity}

The text contains important language requiring States to take measures to deal with overfishing and overcapacity. This language should be strengthened by requiring states to take effective measures, including ensuring that fishing capacity does not exceed the capacity required to catch total allowable catches and quotas. If a fishery is overcapitalized, states should be required to take steps to retire excess vessels.

\section{Assessment of fishing activities}

The text requires that States continuously assess and review fishing activities which may have adverse effects on the conservation of straddling fish stocks and highly migratory fish populations. This requirement should be extended to associated and dependent species.

\section{Associated and dependent species}

Section 3(c) of the text requires states to take into consideration effects on nontarget species with a view to maintaining or restoring populations "above levels at which their reproduction may become seriously threatened." while we recognize this standard comes from the Convention, we believe it is ambiguous and could allow very serious harm to associated and dependent species. At a minimum, the word "seriously" should be removed.

\section{Compatibility}

The issue of compatibility between management measures adopted by a coastal state and those adopted for the same population in international waters is a key obstacle to reaching agreement. Coastal states desire assurances that measures adopted for the high seas will be at least as stringent as those adopted by the coastal state for the same population. Distant water fishing nations argue that the reverse should also apply-that measures adopted for coastal states be at least as stringent as those adopted for the high seas.

We believe the most stringent measures that provide the greatest assurance of long term, continuous sustainability for both target and non-target species should apply throughout the range of the population in question. If the coastal state has adopted more protective measures than those adopted for the adjacent high seas, then the coastal state measures should apply throughout the range, and vice versa. In no case should a coastal state or a regional management organization be prohibited from taking stricter measures as necessary to protect target and non-target species.

\section{Regional Management Organizations and Arrangements}

Section IV on international cooperation contains very important provisions that will improve the way straddling and highly migratory fish are managed. For example, where no regional management arrangement exists, the negotiating text would require states to cooperate to develop conservation and management measures to ensure the continuous long term sustainability of the target fish populations and to preserve the marine environment which supports them. For new and existing regional management organizations, states fishing in a region must participate and must agree on conservation and management measures. The text denies access to states that neither participate nor cooperate, prohibits vessels of non-parties from fishing in a manner contrary to conservation and management measures agreed to by regional management organizations, and authorizes states participating to take measures consistent with international law which they deem necessary to deter such activities. 4

Our major complaint with this section of the text is the weak provisions requiring transparency. The text only provides NGOs the opportunity to participate in meetings "in accordance with the terms and conditions for participation agreed upon by the regional management organization concerned." Since some organizations' terms and conditions allow NGOs to be excluded, this provision will do little or nothing

4 These measures will buttress the recently negotiated flagging agreement, which prohibits some vessels from reflagging to avoid conservation measures. 
to improve the transparency of regional management organizations. This section of the text should be revised to make it clear that NGOs and the public should have full access to information, decision making and other activities of regional management organizations. Specific language is suggested below:

States who are parties to regional fisheries organizations shall review the policies of those organizations to assure that NGOs have the right to attend meetings as participating observers, and that records and reports of the organizations are made available in a timely fashion to those NGOs that express interest. Further, regional and international fishery organizations should be encouraged to include environmental experts from NGOs, as well as fishermen, in' their expert and technical meetings.

\section{E. Compliance and Enforcement}

The text contains strong provisions on compliance, enforcement and binding, compulsory dispute resolution that are essential to effective management and conservation. We have the following recommendations for improvement.

\section{Flag states}

The section of the text on duties of the flag state contains a number of important measures. Flag states should be required to adopt all of them, not "an effective combination" thereof as the text is currently written.

\section{Port states}

The section on port state enforcement allows states to prohibit landings where the catch has been taken in a manner that undermines the effectiveness of applicable conservation and management measures. This section is important and should be expanded to include other measures including trade sanctions.

\section{Enforcement against parties to a regional organization}

The section on nonparticipants in regional management organizations authorizes states to take measures, individually or collectively, which they deem necessary to deter non parties from fishing in a way that undermines the effectiveness of regional management measures. Similar authority must be given to allow states to take measures against parties to a regional management organization who fish in a manner that undermines the effectiveness of regional measures. This is a very important provision that must be included.

In addition, we believe coastal states should be required to implement Section $V$ within their EEZ.

\section{F. Review of the Implementation of the Text}

Regular, public review of implementation of the text will be crucial to holding states accountable. The text requires states and regional organizations to report biennially to the Secretary General on progress made in implementing the provisions, and provides for a full review-of the implementation by a conference to be held five years from the date of adoption of the text.

We recommend that nations and regional organizations be required to report annually to the Secretary General of the United Nations for inclusion in his or her annual report to the General Assembly on the oceans. NGOs should be afforded the opportunity to report to the Secretary General as well. A UN conference to examine implementation should be held three years, not five, from the date of adoption to provide incentives for timely implementation. All reports should also be sent to the Commission on Sustainable Development.

One troubling sentence in this section of the text could undermine the entire document by requiring states and regional organizations to implement the text "based on their capacities and the needs of the region." while we recognize the need for sensitivity to the differing capacities of developing states, we believe this language is excessively broad and creates an enormous potential loophole for both developed and developing nations alike that must be corrected.

\section{G. Minimum Data Requirements}

The provisions in Annex 1 outlining minimum data standards must be made mandatory if they are to have an effect. In addition, there should be a section on minimum data requirements for non-target species of fish and other marine life caught, discarded and landed. "No data/No fishing" requirements should be imposed so that participants in a fishery that fail to report catch and by-catch are excluded from the fishery during the subsequent season. Finally, minimum data requirements should be imposed on all nations fishing for a particular straddling or highly migratory population, both inside and outside EEZs. 


\section{Letter From Greenpeace, Natural Resources Defense Council, World WildLIFE Fund, INC., AND National AUdubon SOCIETY}

JULY 14, 1994.

David Colson,

Department of State,

Washington, DC 20520

DEAR DAVID: Only a litile more than a month remains before the August 15 start of the third substantive session of the UN Conference on Straddling Fish Stocks and Highly Migratory Fish Stocks. The undersigned NGO's urge you and your Government to speak out, prior to and during that session, in favor of two very important matters: (1) a legally binding treaty that addresses conservation and management measures comprehensively, and with real substance; and (2) effective opportunities for NGO's to access key documents and monitor the ongoing negotiations.

Numerous Government officials and the Chair, Ambassador Nandan, participated in intersessional negotiations in Buenos Aires, Argentina, from June 13-17. Important substantive taks occurred during that meeting, including circulation of draft documents (e.g., Canada's new draft treaty). Officials there also committed to preparing, prior to August 15, a more widely agreed treaty text.

It is becoming increasingly clear that the crisis in global fisheries is worsening. In all regions of the world, fish stocks are under serious pressure, some ecosystems have collapsed, and others are seriously impacted. Some nations are taking aggressive actions that imply extensions of their exclusive economic zones, or making public statements which threaten to move in that direction. Fishing fleets continue illegal activities, and tensions between fleets from different nations on the high seas and within national zones is on the rise.

The conference could conclude in a tragedy of international proportions should governments refuse to act collectively and responsibly in its remaining sessions. Moreover, such collective and responsible action must not only address the high seas but also the failure of conservation and management measures within zones of national jurisdiction. To avoid such a tragedy governments must, expeditiously and in good faith, negotiate a legally binding global treaty that contains, inter alia, sufficient substance to ensure:

- stringent conservation and management standards;

- a significant reduction in fishing capacity, which currently far exceeds supply;

- a rapid phase-out of nonselective fishing gear and practices, thereby resulting in major reduction in by-catch, waste and discards;

- obligations to protect the marine environment from adverse effects of nonfishing activities (e.g., marine pollution, habitat degradation), which are integral to fisheries conservation;

- a precautionary and ecosystem approach applied across the ranges of the stocks;

- commitments by coastal states, via "coherence, compatibility" or "consistency" provisions, to adopt and implement strengthened conservation standards;

- effective mechanisms for NGO participation;

- arrangements and mechanisms recognizing the special interests of fisherfolks and fishworkers organizations, coastal communities, women, subsistence and artisanal fishing groups; and

- effective dispute settlement procedures and obligations.

Regarding NGO participation, at the close of the March 1994 session of the conference, NGO's presented an open letter to the chair and delegates, "express[ing] strong concern about the recent exclusion of NGO's from negotiating sessions." the letter observed that such exclusion "contradicts the letter and spirit of Agenda 21 and followup of UNCED," and concluded by saying that:

"NGO organizations and representatives call upon you and all States to in-

clude NGO participation at any intersessional meetings that may take place be-

tween now and the next session, and to ensure NGO participation in August, including in so-called 'informal informals.'"

This call was supported by many delegations in the final plenary session. It is unfortunate that several of these same delegations have failed to followup on public statements supporting NGO participation (e.g., NGO requests to Canadian, U.S. and Argentinian officials to monitor the Buenos Aires meeting were rejected.) Moreover, other governments have failed to respond altogether. We remain well aware of the fact that NGO's have no direct role in the negotiating process, as stated by the Chair at the close of the April 1993 organizational session. However, we believe that-for NGO's and other affected communities-transparency and timely dissemination of information (e.g., early access to the new draft treaty) is not only wise, but essential to the broader and longer term success of this conference. 
Governments, NGO's and other affected stakeholders are in the same "boat," each and all very dependent on and affected by the outcome of the conference. Nonetheless, under the rules of procedure, it is the governments who will decide whether the outcome is a success, or a failure. We fervently hope it will be successful, benefiting the health and long-term viability of the oceans and marine life, as well as the well-being of those whose lives and livelihoods are dependent on the seas.

We urge the U.S. Government to take expedited steps to incorporate the views advanced in this letter. We also would iike to meet with you to discuss these and related issues in advance of the August session. As part of such discussions, we look forward to the public meeting scheduled for July 21 at State. We look forward to hearing from you.

Sincerely,

Clif CurTis,

GERRY LEAPE,

Greenpeace.

LISA SPEER,

SARAH CHASIS,

Natural Resources Defense Council.

Mike SuTTON,

SCOTT BURNS,

World Wildlife Fund, Inc.

Michael Testa,

National Audubon Society.

0 
BOSTON PUBLIC LIBRARY

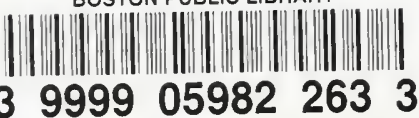



ISBN 0-16-045902-8

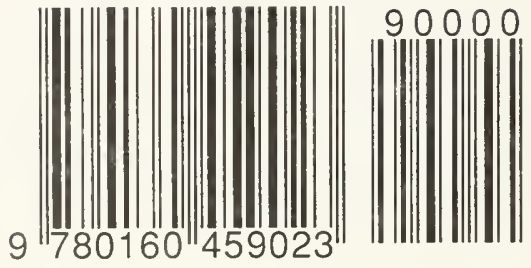

